\title{
Characterization of Alkyl-Nickel Adducts Generated by Reaction of Methyl-Coenzyme M Reductase with Brominated Acids
}

\author{
Mishtu Dey $\ddagger$, Ryan C. Kunz ${ }^{\ddagger}$, Derek M. Lyons ${ }^{\S}$, and Stephen W. Ragsdale ${ }^{\ddagger}, *$ \\ ‡Department of Biochemistry, University of Nebraska, Lincoln, NE 68588 \\ §Simpson College, Indianola, IA 50125
}

\section{Abstract}

\begin{abstract}
Methyl-coenzyme M reductase (MCR) from methanogenic archaea catalyzes the final step in the biological synthesis of methane. Using coenzyme B (CoBSH) as the two-electron donor, MCR reduces methyl-coenzyme $\mathrm{M}$ (methyl-SCoM) to methane and the mixed disulfide, CoB-S-S-CoM. MCR contains Coenzyme $\mathrm{F}_{430}$, an essential redox-active nickel tetrahydrocorphin at its active site. The active form of MCR $\left(\mathrm{MCR}_{\text {red1 }}\right)$ contains $\mathrm{Ni}(\mathrm{I})-\mathrm{F}_{430}$. When 3-bromopropane sulfonate (BPS) is incubated with $\mathrm{MCR}_{\mathrm{red} 1}$, an alkyl-Ni(III) species is formed that elicits the $\mathrm{MCR}_{\mathrm{PS}}$ EPR signal. Here we used EPR and UV-visible spectroscopy and transient kinetics to study the reaction between MCR from Methanothermobacter marburgensis and a series of brominated carboxylic acids, with chain lengths from 4 to 16 carbons long. All of these compounds give rise to an alkyl$\mathrm{Ni}$ intermediate with an EPR signal similar to that of the $\mathrm{MCR}_{\mathrm{PS}}$ species. Reaction of the alkyl$\mathrm{Ni}$ (III) adduct, formed from brominated acids with 8 or less total carbons, with HSCoM as nucleophile at $\mathrm{pH} 10.0$ results in the formation of a thioether coupled to regeneration of the active $\mathrm{MCR}_{\text {red1 }}$ state. When reacted with 4-bromobutyrate, $\mathrm{MCR}_{\text {red1 }}$ forms the alkyl-Ni(III) MCR $\mathrm{XA}$ state and then, surprisingly, undergoes "self-reactivation" to regenerate the $\mathrm{Ni}(\mathrm{I}) \mathrm{MCR}_{\text {red1 }}$ state and a bromocarboxy ester. The results demonstrate an unexpected reactivity and flexibility of the MCR active site to accommodate a broad range of substrates, which act as molecular rulers for the substrate channel in MCR.
\end{abstract}

\begin{abstract}
Methanogenic archaea are anaerobic microbes that form methane as an end product of their metabolism. Methanogens produce approximately 1 billion tons of methane every year, providing a valuable source of renewal energy. On the other hand, methane is a greenhouse gas that is 20 times more potent than $\mathrm{CO}_{2}$ and therefore poses potential environmental problems (1). Methyl coenzyme M reductase (MCR), found in all methanogens, is a nickel containing enzyme that catalyzes the terminal step in biological methane formation, which is the reduction of methyl-coenzyme M (2-(methylthiol)ethane sulfonate, methyl-SCoM) with the two-electron donor coenzyme B, (N-7-mercaptoheptanolyl-threonine phosphate, $\mathrm{CoBSH})$, to form methane and the heterodisulfide CoBS-SCoM (1-3). There is strong evidence that MCR or a MCR-like enzyme also catalyzes the first step in the anaerobic oxidation of methane (4). The active site of MCR contains a redox-active Ni-tetrapyrrolic cofactor called coenzyme $\mathrm{F}_{430}$ (or simply $\mathrm{F}_{430}$ ) that is thought to play an essential role in catalysis (5-7). The crystal structure(s) of MCR reveals that $\mathrm{F}_{430}$ is non-covalently bound to
\end{abstract}

\footnotetext{
"CORRESPONDING AUTHOR CONTACT INFORMATION: Phone: 402-472-2943; FAX: 402-472- 4961; sragsdale1@ unl.edu AFTER AUG 1, 2007: Phone: (734) 763-6459; FAX: (734) 764-3509; sragsdal@umich.edu.

After Aug 1, all authors will be at this address: Department of Biological Chemistry, MSRB III, 5301, 1150 W. Medical Center Drive, Ann Arbor, MI 48109-0606

Supporting Information Available. Eight figures showing second order rate constant determination for the formation of various MCRXA complexes. This material is available free of charge via the Internet at http://pubs.acs.org
} 
MCR and sits at the bottom of a $30 \AA$ hydrophobic channel (8) that is sufficiently deep to accommodate both substrates.

The Ni atom of $\mathrm{F}_{430}$ in MCR can exist in 3 different oxidation states, each exhibiting several coordination states. Active $\mathrm{MCR}_{\text {red } 1}$ contains $\mathrm{Ni}(\mathrm{I})$, which is the form that can react with methyl-SCoM to catalyze methane formation $(9,10)$. In addition to $\mathrm{MCR}_{\text {red } 1}$, two other states of MCR that could be relevant for the catalytic mechanism are $\mathrm{MCR}_{\mathrm{Ox} 1}$ and $\mathrm{MCR}_{\mathrm{PS}}$.

Based on spectroscopic and computational studies, $\mathrm{MCR}_{\mathrm{Ox} 1}$ is best described as a high spin $\mathrm{Ni}(\mathrm{II}) /$ thiyl-radical that is in resonance with a $\mathrm{Ni}(\mathrm{III}) /$ thiolate species $(11,12) . \mathrm{MCR}_{\mathrm{ox} 1}$ resembles a proposed catalytic intermediate and is called the "ready state" (9) because it can be converted to $\mathrm{MCR}_{\text {red1 }}$ in vitro by incubation with the low potential reductant, titanium(III) citrate (Ti(III) citrate) (10). $\mathrm{MCR}_{\mathrm{ox} 1}$ is generated in vivo by treating the actively growing cells with sodium sulfide (13) or alternatively, by switching the gas from $80 \% \mathrm{H}_{2} / 20 \% \mathrm{CO}_{2}$ to $80 \% \mathrm{~N}_{2} / 20 \% \mathrm{CO}_{2}$ (14). $\mathrm{MCR}_{\mathrm{ox} 1}$ can be generated in vitro by treating $\mathrm{MCR}_{\mathrm{red} 2}\left(\mathrm{MCR}_{\mathrm{red} 1}\right.$ in the presence of $\mathrm{HSCoM}$ and $\left.\mathrm{CoBSH}\right)$ with polysulfide (15).

The second state of MCR that may be relevant for catalysis is $\mathrm{MCR}_{\mathrm{PS}}$ (formerly $\mathrm{MCR}_{\mathrm{BPS}}$ ) (16). $\mathrm{MCR}_{\mathrm{PS}}$ has been described as a high-spin $\mathrm{Ni}(\mathrm{II}) /$ alkylsulfonate radical species resonating with a $\mathrm{Ni}(\mathrm{III}) / \mathrm{alkyl}$ species $(17,18)$, and, thus, resembles the proposed methyl-Ni catalytic intermediate. $\mathrm{MCR}_{\mathrm{PS}}$ is generated in vitro by incubating $\mathrm{MCR}_{\mathrm{red} 1}$ with 3bromopropane sulfonate (BPS) (16), which is a potent inhibitor (apparent $\left.K_{i}=50 \mathrm{nM}\right)(19$, 20) of MCR that also has been classed as an irreversible inhibitor (21). However, when it was recognized that the $\mathrm{MCR}_{\mathrm{PS}}$ state can be converted back to the active $\mathrm{MCR}_{\text {red1 }}$ state by reacting with thiolates, reversing inhibition, BPS was classified as a reversible redox inactivator (22). Thus, both $\mathrm{MCR}_{\mathrm{PS}}$ and $\mathrm{MCR}_{\mathrm{Ox} 1}$ are "ready" states that can generate $\mathrm{MCR}_{\text {red } 1}$ in vitro; furthermore, they exhibit similar UV-visible and EPR spectra.

The two mechanisms for methane formation can be distinguished by the first step of catalysis (Figure 1). In Mechanism I, which is based on the crystal structure and mechanistic work with $\mathrm{F}_{430}$ model complexes (23-25), nucleophilic attack of $\mathrm{Ni}(\mathrm{I})-\mathrm{MCR}_{\text {red1 }}$ on the methyl group of methyl-SCoM generates a methyl-Ni intermediate (26). Although a true methyl-Ni intermediate has not been described upon reaction of $\mathrm{MCR}_{\text {red1 }}$ with the native substrate methyl-SCoM, the reaction of BPS and other alkyl halides with $\mathrm{MCR}_{\text {red1 }}$ generates an alkyl-Ni(III) species that is subsequently attacked by free organic thiolates to generate the thioether product and $\mathrm{MCR}_{\mathrm{red} 1}$ (22). This reaction is analogous to that of the reaction catalyzed by methionine synthase, where homocysteine acts as a nucleophile to reduce methyl-Co(III) to form $\mathrm{Co}(\mathrm{I})$ and methionine (27).

Mechanism II, which is based on density function theory computations $(28,29)$, avoids the methyl-Ni(III) species because cleavage of the strong methyl-S bond of methyl-SCoM to form a relatively weak methyl-Ni(III) species was calculated to be extremely endothermic (45 kcal $/ \mathrm{mol})$. Therefore, Mechanism II proposes attack of $\mathrm{Ni}(\mathrm{I})$ on the sulfur atom adjacent to the methyl group of methyl-SCoM resulting in homolytic cleavage of the methyl-sulfur bond to generate a methyl radical and a $\mathrm{Ni}(\mathrm{III})$-thiolate/Ni(II)-thiol-radical complex

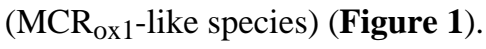

It was recently shown (22) that the alkyl-Ni(III) species $\left(\mathrm{MCR}_{\mathrm{PS}}\right)$ can be converted to the active $\mathrm{MCR}_{\mathrm{red} 1}$ state when it is reacted with various thiols at $\mathrm{pH} 10.0$. The $\mathrm{MCR}_{\mathrm{PS}}$ intermediate is chemically similar to the proposed alkyl-Ni intermediate in the first step of Mechanism I; however, the position of attack on BPS is stereochemically comparable to the first step in Mechanism II. The position of attack by $\mathrm{Ni}(\mathrm{I})$ is probably influenced by the placement of BPS (or other analogs) in the active site. Based on the $\mathrm{MCR}_{\mathrm{ox} 1 \text {-silent }}$ crystal 
structure, the sulfonate group of HSCoM is firmly anchored by three contacts at the "back" of the active site and the thiolate is ligated to Ni. Similarly, the reactivity of CoBSH would be influenced by its location in the substrate channel relative to the position of the Ni-bound ligand. CoBSH has phosphate and carboxylate groups that anchor it to the upper lip of the channel and an alkyl chain that leads into the active site and terminates in a thiol group 8.7 $\AA$ from the nickel atom of $\mathrm{F}_{430}$ (8).

In order to better understand the selectivity of the MCR reaction toward nucleophilic attack by $\mathrm{Ni}(\mathrm{I})$, one could compare the reactivity of a series of brominated sulfonates of varying chain length. However, such a series of compounds is not commercially available. On the other hand, substitution of the sulfonate of BPS with a carboxylate still allows formation of a $\mathrm{MCR}_{\mathrm{PS}}$-like signal (22), which we call MCR $\mathrm{XA}_{\mathrm{A}}$. Furthermore, methylmercaptopropionate is a substrate for MCR $\left(\mathrm{k}_{\text {cat }} / \mathrm{K}_{\mathrm{M}}=26 \mathrm{M}^{-1} \mathrm{~s}^{-1}\right)$, albeit $\sim 110$-fold less reactive than the natural substrate, methyl-SCoM $\left(\mathrm{k}_{\mathrm{cat}} / \mathrm{K}_{\mathrm{M}}=2.8 \times 10^{3} \mathrm{M}^{-1} \mathrm{~s}^{-1}\right)(30)$, and bromopropionate (like BPS) is an inhibitor (18), indicating that brominated carboxylic acids mimic the interactions of BPS and methyl-SCoM at the MCR active site. Therefore, in order to better understand the selectivity of the MCR reaction, we have in this paper compared the reactivity of a series of brominated compounds of varying chain lengths in formation of the alkyl-Ni(III) complexes and in the subsequent reaction with organic thiol to regenerate the active enzyme.

Here we show that various brominated acids ranging from the relatively small bromobutyric acid $(\mathrm{Br} 4 \mathrm{~A})$ to the relatively large bromohexadecanoic acid (Br16A) can all react with $\mathrm{MCR}_{\text {red1 }}$ to form an EPR-active species, $\mathrm{MCR}_{\mathrm{XA}}$, that is nearly identical to $\mathrm{MCR}_{\mathrm{PS}}$. Based on the present studies a model has been proposed for the mode of binding of various brominated acids of different chain lengths that can be classified as: (a) methyl-SCoM-like and (b) CoBSH-like. The results provide information on the selectivity of MCR for its substrates (methyl-SCoM, CoBSH and BPS) and may aid in the development of other substrate analogs or inhibitors of MCR.

\section{Materials and Methods}

\section{Materials and Organism}

Methanothermobacter marburgensis (f. Methanobacterium thermoauotrophicum strain Marburg) was obtained from the Oregon Collection of Methanogens (Portland, OR) catalogue as OCM82. All buffers, media ingredients, and other reagents were acquired from Sigma-Aldrich (St. Louis, MO) unless otherwise stated and were of the highest purity available. Solutions were prepared using Nanopure deionized water. $\mathrm{N}_{2}(99.98 \%), \mathrm{H}_{2} \mathrm{~S}(99.0$ $\%), \mathrm{H}_{2} / \mathrm{CO}_{2}(80 \% / 20 \%)$, and Ultra High Purity (UHP) $\mathrm{H}_{2}(99.999 \%)$ were obtained from Linweld (Lincoln, NE). Ti(III) citrate solutions were prepared from a stock solution of 200 $\mathrm{mM} \mathrm{Ti}(\mathrm{III})$ citrate, which was synthesized by adding an aqueous solution of sodium citrate (5.8 g sodium citrate added to $20 \mathrm{ml} \mathrm{H}_{2} \mathrm{O}$ ) to Ti(III) trichloride ( 30 weight \% solution in 2 $\mathrm{M}$ hydrochloric acid) (Acros Organics, Morris Plains, NJ) under anaerobic conditions and adjusting the $\mathrm{pH}$ to 7.0 with a saturated solution of sodium bicarbonate (31). The concentration of Ti(III) citrate was determined routinely by titrating a methyl viologen solution.

\section{M. marburgensis growth, harvest and $\mathbf{M C R}_{\text {red1 }}$ purification conditions}

$\mathrm{MCR}_{\text {red1 }}$ was isolated from $M$. marburgensis cultured on $\mathrm{H}_{2} / \mathrm{CO}_{2} / \mathrm{H}_{2} \mathrm{~S}(80 \% / 20 \% / 0.1 \%)$ at $65^{\circ} \mathrm{C}$ in a 14-L fermentor (New Brunswick Scientific Co., Inc. New Brunswick, NJ) (9). Culture media were prepared as previously described (32). $\mathrm{MCR}_{\mathrm{red} 1}$ was generated in vivo and purified as described earlier (22). The purification procedure routinely generates 60-70 $\% \mathrm{MCR}_{\mathrm{red} 1}$ as determined by UV-visible and EPR spectroscopy described earlier (22) 


\section{Spectroscopy of MCR}

UV-visible spectra of MCR were recorded in the anaerobic chamber using a diode array spectrophotometer (Model DT 1000A, Analytical Instrument Systems, Inc., Flemingron, NJ). EPR spectra were recorded on a Bruker EMX spectrometer (Bruker Biospin Corp., Billerica, MA), equipped with an Oxford ITC4 temperature controller, a Hewlett-Packard Model 5340 automatic frequency counter and Bruker gaussmeter. Unless otherwise noted, the EPR spectral parameters included: temperature, $70 \mathrm{~K}$; microwave power, $10 \mathrm{~mW}$; microwave frequency, $9.43 \mathrm{GHz}$; receiver gain, $2 \times 10^{4}$; modulation amplitude, $10.0 \mathrm{G}$; modulation frequency, $100 \mathrm{kHz}$. Double integrations of the EPR spectra were performed and referenced to a $1 \mathrm{mM}$ copper perchlorate standard.

\section{Stopped-Flow Studies}

Stopped-flow experiments were carried on an Applied Photophysics spectrophotometer (SX.MV18, Leatherhead, UK) equipped with a photodiode array detector. Rigorous measures were taken to remove oxygen from the stopped-flow instrument. Buffered solutions of enzymes and inhibitors were made in the anaerobic chamber in $0.5 \mathrm{M} \mathrm{Tris}-\mathrm{HCl}$, $\mathrm{pH} 7.6$ containing $0.2 \mathrm{mM} \mathrm{Ti}$ (III) citrate at $25^{\circ} \mathrm{C}$. All buffered solutions contained $0.2 \mathrm{mM}$ $\mathrm{Ti}(\mathrm{III})$ citrate as an oxygen scavenger, since exclusion of $\mathrm{Ti}(\mathrm{III})$ citrate resulted in oxidation of $\mathrm{MCR}_{\mathrm{red} 1}$. The solutions were then loaded into tonometers, which had been incubated in the anaerobic chamber for at least 4 days and served as reservoirs for the drive syringes of the stopped-flow instrument. The drive syringes and mixing chamber were made anaerobic by flushing the syringe chamber with a dithionite:resazurin $(1 \mathrm{mM}: 0.02 \mathrm{mM})$ solution in $0.1 \mathrm{M} \mathrm{NaOH}$. $\mathrm{MCR}_{\text {red } 1}$ and varied concentrations of brominated acids were rapidly mixed at $25^{\circ} \mathrm{C}$ in a $1: 1$ ratio. The reaction was monitored in the single wavelength mode by following the decrease of $\mathrm{MCR}_{\mathrm{red} 1}$ at $385 \mathrm{~nm}$ and $\mathrm{MCR}_{\mathrm{XA}}$ formation was followed at 420 $\mathrm{nm}$, with a $1 \mathrm{~cm}$ pathlength. Data were fit to a single exponential decay and exponential rise to maximum functions, respectively, using software provided by Applied Photophysics (version SX MV.18) or using Sigma Plot 2001 (Point Richmond, CA). Reported rate constants are the average of at least three different rapid-mixing experiments.

\section{Mass spectromety}

All mass spectra (LCMS) were collected in negative ion modes by direct infusion to a [4000 Qtrap (ABS)] mass spectrometer using a kD Scientific micro flow syringe pump. The data was acquired and processed using Analyst 1.4.1 software. Data was acquired in Q1 (quadrupole one) and Product ion scan in negative ion mode. The mass range of 50-300 amu (atomic mass units) was scanned in $1 \mathrm{~s}$. The ionspray voltage was set to $-4500 \mathrm{~V}$, the temperature was set to $22{ }^{\circ} \mathrm{C}$ and a declustering potential (DP) value was $-50 \mathrm{~V}$. $\mathrm{MCR}_{\text {red } 1}$ $(10 \mu \mathrm{M})$ was incubated for $10 \mathrm{~min}$ with $2.0 \mathrm{mM}$ 4-bromobutyric acid (Br4A was prepared as a stock solution in $0.1 \mathrm{M}$ formic acid; thus, the final concentration of formic acid in the

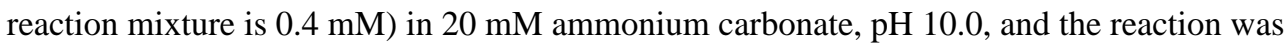
followed by UV-visible spectroscopy. For, the regeneration of $\mathrm{MCR}_{\mathrm{red} 1}$ from $\mathrm{MCR}_{\mathrm{XA}}$ with HSCoM, typically $20 \mu \mathrm{M} \mathrm{MCR}_{\text {red } 1}$ was reacted with $1 \mathrm{mM}$ brominated acid in $50 \mathrm{mM}$ ammonium carbonate, $\mathrm{pH} 10$ to form $\mathrm{MCR}_{\mathrm{XA}}$, which was then reacted with $20 \mathrm{mM}$ HSCoM. This reaction was monitored by UV-visible spectroscopy. After $\mathrm{MCR}_{\text {red1 }}$ was fully reactivated, assessed by reaching a stable maximum absorbance of the $385 \mathrm{~nm}$ band, the reaction was stopped by freezing in liquid nitrogen. For analysis, the frozen liquid was thawed and, subsequently, enzyme and ligands were separated using a $0.5 \mathrm{~mL}$ Microcon centrifugal filter device with a $30 \mathrm{KDa}$ cut-off filter (Millipore, Billerica, MA). The filtrate containing the product was collected and stored at $4{ }^{\circ} \mathrm{C}$ until it was assayed by mass spectrometry. All MS samples were prepared by mixing the ligand solution with an equal volume of acetonitrile. 


\section{Reactions between $\mathbf{M C R}_{\text {red1 }}$ and brominated acids}

$\mathrm{MCR}_{\text {red1 }}$ (typically 0.01-0.02 mM) was incubated in $50 \mathrm{mM}$ Tris- $\mathrm{HCl}(\mathrm{pH} 7.6)$ at $25{ }^{\circ} \mathrm{C}$ for $0.5-2 \mathrm{~min}$, with various brominated acids at concentrations between $0.1 \mathrm{mM}$ and $2 \mathrm{mM}: 0.2$ $\mathrm{mM}$ 4-bromobutyric acid (Br4A) in $0.1 \mathrm{mM}$ final formic acid concentration, $0.2 \mathrm{mM} 5$ bromovaleric acid (Br5A), $0.2 \mathrm{mM}$ 6-bromohexanoic acid (Br6A), $1.0 \mathrm{mM} 7$ bromoheptanoic acid (Br7A) (Karl Industries Inc., Aurora, OH and Matrix Scientific, Columbia, SC), $0.1 \mathrm{mM}$ 8-bromooctanoic acid (Br8A), $0.2 \mathrm{mM}$ 9-bromononanoic acid (Br9A) (Matrix Scientific), $0.2 \mathrm{mM}$ 10-bromodecanoic acid (Br10A) (Matrix Scientific), 1.0 mM 11-bromoundecanoic acid (Br11A) (Fluka, St.Louis, MO), $1.0 \mathrm{mM} \mathrm{12-}$ bromododecanoic acid (Br12A) (Fluka), $1.0 \mathrm{mM}$ 15-bromopentadecanoic acid (Br15A) (Fluka), and $0.5 \mathrm{mM} 16$-bromohexadecanoic acid (Br16A). All brominated acid solutions, with the exception of $\mathrm{Br} 4 \mathrm{~A}$, were made in $100 \%$ ethanol. The rate and extent of formation of new $\mathrm{MCR}_{\mathrm{XA}}$ complexes was measured by EPR spectroscopy (Table 1).

Special precautions were required for working with 4-bromobutyric acid (Br4A). This compound is unstable in neutral and alkaline solutions; therefore, all experiments were performed by dissolving it in $0.1 \mathrm{M}$ formic acid. Attempts to make a solution of $\mathrm{Br} 4 \mathrm{~A}$ in neutral or high $\mathrm{pH}$ solutions or in ethanol resulted in degradation of the acid as we inferred by a decrease in reactivity of $\mathrm{Br} 4 \mathrm{~A}$ with $\mathrm{MCR}_{\text {red1 }}$ as a function of time.

\section{Results}

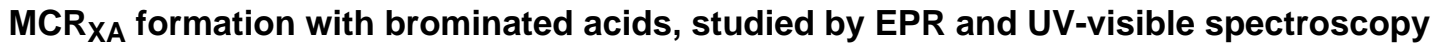

Kinetic and spectroscopic studies indicate that, when $\mathrm{MCR}_{\text {red1 }}$ reacts with BPS, bromide is eliminated to generate a six-coordinate $\mathrm{Ni}(\mathrm{III})$-complex with propylsulfonate as the upper axial ligand, which undergoes protonation to form propanesulfonate $(17,18,22)$. This reaction is analogous to the reaction of $\mathrm{MCR}_{\text {red1 } 1}$ to generate a methyl-Ni(III) intermediate in methane formation with the natural substrate, methyl-SCoM. Here we expand on a previous study to determine the range of BPS analogs that are accommodated by MCR (22). Instead of sulfonates, we used a series of commercially available brominated carboxylic acids. As described in the Introduction, we hypothesized that the reaction between $\mathrm{MCR}_{\text {red1 }}$ and brominated acids is similar to that with BPS. To test this hypothesis, EPR and UV-visible spectroscopies were used to observe the formation of the Ni(III)-alkanoic acid complex(s), and stopped-flow experiments were conducted to characterize the kinetic parameters for the reactions. Since $\mathrm{MCR}_{\mathrm{XA}}$ (alkyl-Ni(III)) and $\mathrm{MCR}_{\text {silent }}(\mathrm{Ni}(\mathrm{II})$ ) exhibit similar UV-visible spectra, unambiguous quantification of the amount of $\mathrm{MCR}_{\mathrm{red} 1}$ and of $\mathrm{MCR}_{\mathrm{XA}}$ was performed by EPR spectroscopy by comparing the doubly integrated signal intensity with that of a $\mathrm{Cu}$ standard. The concentration of $\mathrm{MCR}_{\text {silent }}$ is then equal to the difference between the initial concentration of $\mathrm{MCR}_{\mathrm{red} 1}$ and the amount of $\mathrm{MCR}_{\mathrm{XA}}$. Brominated acids used in this study are abbreviated as BrXA, where $\mathrm{X}$ refers to total length of the chain (between 4 and 16 carbons long) including the terminal carboxyl group (A).

$\mathrm{MCR}_{\text {red1 }}$ reacts with brominated acids that are 4 to 16 carbons in length according to Equation 1 to form $\mathrm{MCR}_{\mathrm{XA}}(\mathrm{X}=4-16)$, which elicits an EPR signal nearly identical to that of $\mathrm{MCR}_{\mathrm{PS}}$ (Table 1). A representative EPR spectrum of $\mathrm{MCR}_{\text {red1 }}$ and $\mathrm{MCR}_{7 \mathrm{~A}}$, the product of the reaction between $\mathrm{MCR}_{\text {red1 }}$ and Br7A, is shown in Figure 2.

$$
\mathrm{MCR}_{\text {red } 1}+\mathrm{BrXA} \rightarrow \mathrm{MCR}_{\mathrm{XA}}+\mathrm{Br}^{-} \text {Equation (1) }
$$

The near identity of the EPR spectrum of the alkyl-Ni(III) $\mathrm{MCR}_{\mathrm{PS}}$ state with that of $\mathrm{MCR}_{\mathrm{XA}}$ strongly indicates that the reaction of $\mathrm{MCR}_{\mathrm{red} 1}$ with the bromoacids also generates an alkyl$\mathrm{Ni}(\mathrm{III})$ species. The different $\mathrm{MCR}_{\mathrm{XA}}$ complexes accumulate to varying amounts, as 
reported in Table 1. Those generated from the shorter brominated acids, Br10A and below, form quickly and accumulate to fairly high amounts during a 2-min reaction at room temperature. The shortest acid tested is $\mathrm{Br} 4 \mathrm{~A}$, which had earlier been reported to form a $\mathrm{MCR}_{\mathrm{PS}}$-like species $(17,18,22)$. When reacted with $\mathrm{MCR}_{\text {red1 }}, \mathrm{Br} 4 \mathrm{~A}$ completely converts to the $\mathrm{MCR}_{4 \mathrm{~A}}$ species; however, this reaction is unique and is discussed in more detail below. 3-Bromopropionate $(\mathrm{Br} 3 \mathrm{~A})$ was not tested although it has been reported not to form the $\mathrm{MCR}_{\mathrm{XA}}$ signal (18). Br3A is an analog of 2-bromoethanesulfonate (BES) and like BES $\left([\mathrm{I}]_{0.5 \mathrm{~V}}=2 \mu \mathrm{M}\right)$, quenches the $\mathrm{MCR}_{\text {red1 } 1}$ signal by the oxidation of the enzyme from $\mathrm{Ni}(\mathrm{I})$ to an EPR-silent Ni (34) state, thus BES and hence, Br3A appears to act as irreversible inhibitors of MCR (18).

The $\mathrm{MCR}_{\mathrm{XA}}$ species formed from the longer $(\mathrm{X}=11,12,15$, and 16) brominated acids accumulate to less than $10 \%$ within $1 \mathrm{~min}$ at $25^{\circ} \mathrm{C}$, indicating that these complexes form transient species that form and decay more rapidly than the time it takes to hand mix and freeze the samples. When these brominated acids were reacted with $\mathrm{MCR}_{\text {red } 1}$ at $4{ }^{\circ} \mathrm{C}$ and frozen within $\sim 30$ secs in an EPR tube, accumulation of the corresponding MCR $\mathrm{XA}_{\mathrm{X}}$ species markedly increased (Table 1). We suggest that the $\mathrm{MCR}_{\mathrm{XA}}$ complexes formed with the longer brominated acids are not well anchored to the active site and, thus, escape from the radical cage and dissociate rapidly from the substrate binding channel in MCR. To better understand the reactions of $\mathrm{MCR}_{\text {red1 }}$ with the bromoacids, stopped flow experiments were performed.

\section{Reaction of $\mathrm{MCR}_{\text {red1 }}$ with brominated acids and $M C R_{\mathrm{XA}}$ formation followed by stopped- flow}

Formation of the EPR-active $\mathrm{MCR}_{\mathrm{XA}}$ state is accompanied by a $35 \mathrm{~nm}$ red shift relative to $\mathrm{MCR}_{\text {red1 }}$ (Figure 3). Exhibiting absorption maxima at $420 \mathrm{~nm}$, the UV-visible absorption spectra of $\mathrm{MCR}_{\mathrm{XA}}$ resemble those of $\mathrm{MCR}_{\mathrm{PS}}$ (alkyl-Ni(III)), $\mathrm{MCR}_{\mathrm{ox} 1}$ (RS-Ni(III)), and $\mathrm{MCR}_{\text {silent }}(\mathrm{Ni}(\mathrm{II}))$.

Stopped-flow UV-visible spectroscopy was used to obtain kinetic parameters for the reaction of $\mathrm{MCR}_{\mathrm{red} 1}$ with the brominated acids by monitoring the absorption bands at 385 $\mathrm{nm}$ and $420 \mathrm{~nm}$ to follow the decay of $\mathrm{MCR}_{\mathrm{red} 1}$ and formation of $\mathrm{MCR}_{\mathrm{XA}}$, respectively. For the reaction with each of the brominated acids, the rate constant $(\mathrm{k})$ could be obtained by a single exponential equation, which adequately fit the data. The rate of decay of $\mathrm{MCR}_{\text {red } 1}$ matches the rate of $\mathrm{MCR}_{\mathrm{XA}}$ formation, which indicates that there are no intermediates in the conversion of $\mathrm{MCR}_{\mathrm{red} 1}$ to $\mathrm{MCR}_{\mathrm{XA}}$, or that any intermediates are too transient to be observed. These rate constants were plotted versus the $\mathrm{BrXA}$ concentrations to determine the second order rate constant $\left(\mathrm{k}_{\max } / \mathrm{K}_{\mathrm{M}}\right)$ for $\mathrm{MCR}_{\mathrm{XA}}$ formation as exemplified for $\mathrm{Br} 7 \mathrm{~A}$ in Figure 4. The second order rate constants for formation of the $\mathrm{MCR}_{\mathrm{XA}}$ complexes with the shorter and medium length acids $(X=5-10)$ are between 20-60 $\mathrm{M}^{-1} \mathrm{~s}^{-1}$ (Table 1, Figures S1-S5), with the exception of $\mathrm{MCR}_{7 \mathrm{~A}}$, which has a second order rate constant of $140 \mathrm{M}^{-1}$ $\mathrm{s}^{-1}$. The second order rate constants for formation of $\mathrm{MCR}_{11 \mathrm{~A}}, \mathrm{MCR}_{12 \mathrm{~A}}$ and $\mathrm{MCR}_{15 \mathrm{~A}}$ (Table 1, Figures S6-S8) are significantly higher. The $\mathrm{k}_{\max }$ and $\mathrm{K}_{M}$ values for $\mathrm{MCR}_{16 \mathrm{~A}}$ could not be determined due to solubility issues involved with Br16A concentrations above $0.5 \mathrm{mM}$. However, with the available concentrations, a linear fit of the data established a second order rate constant of $60 \mathrm{M}^{-1} \mathrm{~s}^{-1}$ (Table 1, Figure S9).

The kinetics for formation of these $\mathrm{MCR}_{\mathrm{XA}}$ complexes can be compared to those for formation of their similarly sized sulfonate cousins, $\mathrm{MCR}_{\mathrm{PS}}$ and $\mathrm{MCR}_{\mathrm{BS}}$, and to the rate of methane formation from methyl-SCoM. $\mathrm{MCR}_{4 \mathrm{~A}}$ is formed with an overall second order rate constant of $170 \mathrm{M}^{-1} \mathrm{~s}^{-1}$, which is 1000 times lower than that for formation of $\mathrm{MCR}_{\mathrm{PS}}(2.3 \times$ $10^{3} \mathrm{M}^{-1} \mathrm{~s}^{-1}$ at $\left.25^{\circ} \mathrm{C}\right)(17,18,22)$. However, the $\mathrm{k}_{\max }$ values for these reactions are nearly identical $\left(\mathrm{MCR}_{\mathrm{PS}}, 17 \mathrm{~s}^{-1}, \mathrm{MCR}_{4 \mathrm{~A}}, 15 \mathrm{~s}^{-1}\right)$; therefore, the decreased catalytic efficiency for 
the formation of $\mathrm{MCR}_{4 \mathrm{~A}}$ relative to $\mathrm{MCR}_{\mathrm{PS}}$ comes exclusively from the difference in $\mathrm{K}_{\mathrm{M}}$ values for these two substrates, $\sim 90 \mathrm{mM}$ for Br4A and $\sim 0.09 \mathrm{mM}$ for BPS. On the other hand, the $\mathrm{k}_{\max } / \mathrm{K}_{\mathrm{M}}$ for $\mathrm{MCR}_{4 \mathrm{~A}}$ formation is only 5.4-fold lower than the $\mathrm{k}_{\mathrm{cat}} / \mathrm{K}_{\mathrm{M}}$ for methane formation from methyl-SCoM $\left(930 \mathrm{M}^{-1} \mathrm{~s}^{-1}\right.$ at $20{ }^{\circ} \mathrm{C}, 1.9 \times 10^{4} \mathrm{M}^{-1} \mathrm{~s}^{-1}$ at $\left.65^{\circ} \mathrm{C}\right)$ and the $\mathrm{k}_{\max }$ value is actually 3 -fold higher than the $\mathrm{k}_{\text {cat }}$ for methane formation at $20^{\circ} \mathrm{C}$. The second order rate constant for $\mathrm{MCR}_{5 \mathrm{~A}}$ formation $\left(31 \mathrm{M}^{-1} \mathrm{~s}^{-1}\right)$ is 70 -fold lower than that for formation of $\mathrm{MCR}_{\mathrm{BS}}\left(2.3 \times 10^{3} \mathrm{M}^{-1} \mathrm{~s}^{-1}\right)$, the analogous sulfonate complex, resulting from a 7-fold increase in $K_{M}$ and a $\sim 10$-fold decrease in $k_{\max }$. The reactions of $M_{C R}$ red1 with Br7A and Br8A exhibit kinetic parameters similar to those of the shorter bromoacids with near or complete conversion to $\mathrm{MCR}_{7 \mathrm{~A}}$ and $\mathrm{MCR}_{8 \mathrm{~A}}$. For example, $\mathrm{MCR}_{7 \mathrm{~A}}$ formation occurs with a second order rate constant of $140 \mathrm{M}^{-1} \mathrm{~s}^{-1}$, the $\mathrm{k}_{\max }$ values are rather high ( 2-3 $\mathrm{s}^{-1}$ ) and the $\mathrm{K}_{\mathrm{M}}$ values are similar to those of methyl-SCoM. We conclude that the short chain brominated acids are positioned in the active site much like methyl-SCoM and HSCoM and react similarly to BPS.

There is a marked drop in both $\mathrm{k}_{\max }$ and $\mathrm{K}_{\mathrm{M}}$ values for the reactions of $\mathrm{MCR}_{\mathrm{red}}$ with $\mathrm{Br} 9 \mathrm{~A}$, Br10A, Br12A, Br15A and Br16A (Table 1, Figures S4, S5 and S7-S9). The $\mathrm{K}_{\mathrm{M}}$ values for most of these BrXA fall in the range of the $\mathrm{K}_{\mathrm{M}}$ for CoBSH $(\sim 0.2 \mathrm{mM})(21)$ and the values of $\mathrm{k}_{\max } / \mathrm{K}_{\mathrm{M}}$ for the reactions with $\mathrm{Br} 11 \mathrm{~A}, \mathrm{Br} 12 \mathrm{~A}$ and $\mathrm{Br} 15 \mathrm{~A}$ are similar to the $\mathrm{k}_{\mathrm{cat}} / \mathrm{K}_{\mathrm{M}}$ for CoBSH $\left(2.2 \times 10^{3} \mathrm{M}^{-1} \mathrm{~s}^{-1}, 20^{\circ} \mathrm{C}\right)$ in methane formation (26), suggesting that these long chain bromoacids are recognized by MCR as CoBSH analogs. Based on a simple structural analysis using ChemDraw (Figure 5), the negatively charged oxygen on the carboxyl group of Br10A would be in the same position as the carboxylate oxygen of $\mathrm{CoBSH}$ and the oxygen from the carboxylate of Br12A would occupy the same position as the phosphate oxygen of $\mathrm{CoBSH}$. The corresponding $\mathrm{MCR}_{\mathrm{XA}}$ complexes decay more rapidly than those formed from the shorter BPS-like bromoacids, with $<10 \%$ of the $\mathrm{MCR}_{\mathrm{XA}}$ complex accumulating when mixed at room temperature (Table 1). The yield of EPR-active $\mathrm{MCR}_{\mathrm{XA}}$ could be increased to $\sim 20-40 \%$ by performing the reaction at $4{ }^{\circ} \mathrm{C}$.

Although Br11A reacts very rapidly with $\mathrm{MCR}_{\text {red1 }}$, we did not observe saturation even at 60 $\mathrm{mM}$ concentrations; therefore, there is a relatively high standard error associated with both the $\mathrm{K}_{\mathrm{M}}(200 \mathrm{mM})$ and $\mathrm{k}_{\max }\left(380 \mathrm{~s}^{-1}\right)$ values shown in Table 1 . The second order rate constant for $\mathrm{MCR}_{11 \mathrm{~A}}$ formation determined from a linear fit $\left(1500 \pm 80 \mathrm{M}^{-1} \mathrm{~s}^{-1}\right)$ is more accurate and is in reasonable agreement with that determined from a hyperbolic fit (1900 $\mathrm{M}^{-1} \mathrm{~s}^{-1}$ ). Due to the low solubility of Br15A and Br16A, kinetic parameters were determined using brominated acid concentrations no greater than $0.5 \mathrm{mM}$. Regardless, the $\mathrm{k}_{\mathrm{obs}} / \mathrm{K}_{\mathrm{M}}$ values are comparable to that obtained with $\mathrm{Br} 11 \mathrm{~A}$; for example, for the reaction of $\mathrm{Br} 15 \mathrm{~A}$ with $\mathrm{MCR}_{\text {red1 }}$, the second order rate constant is $1600 \mathrm{M}^{-1} \mathrm{~s}^{-1}$ (Figure S8). Then, with Br16A, saturation could not be reached and the $\mathrm{k}_{\max } / \mathrm{K}_{\mathrm{M}}$ value, determined from a linear fit is $57 \mathrm{M}^{-1} \mathrm{~s}^{-1}$.

\section{Reaction of $M C R_{\text {red1 }}$ with $B r 4 A$ - self-reactivation of $M C R_{4 A}$ to form $M C R_{\text {red }}$}

When the reaction between $\mathrm{MCR}_{\text {red } 1}$ and $\mathrm{Br} 4 \mathrm{~A}$ was monitored by UV-visible and EPR spectroscopy, $\mathrm{MCR}_{\text {red1 }}$ was shown to quantitatively convert to $\mathrm{MCR}_{4 \mathrm{~A}}$., as shown earlier $(17,18,22)$; however, when lower concentrations $(\sim 0.2 \mathrm{mM})$ of $\mathrm{Br} 4 \mathrm{~A}$ were used, a rapid decrease in absorbance at $385 \mathrm{~nm}$ due to formation of $\mathrm{MCR}_{4 \mathrm{~A}}$ was observed, followed by a gradual increase in absorbance at $385 \mathrm{~nm}$ after $\sim 1 \mathrm{~min}$ (Figure 6), which corresponds to the

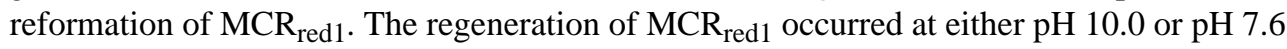
in the absence of free thiols, which were shown to convert $\mathrm{MCR}_{\mathrm{PS}}$ to $\mathrm{MCR}_{\mathrm{red} 1}$ at $\mathrm{pH} 10.0$ $(17,18,22)$.

The rate of $\mathrm{MCR}_{4 \mathrm{~A}}$ generation depends on the $\mathrm{Br} 4 \mathrm{~A}$ concentration, with a second order rate constant of $170 \pm 12 \mathrm{M}^{-1} \mathrm{~s}^{-1}\left(\mathrm{k}_{\max }, 15 \mathrm{~s}^{-1} ; \mathrm{K}_{\mathrm{M}}, 89 \mathrm{mM}\right)$ (Figure S10), while the rate 
constant for regeneration of $\mathrm{MCR}_{\mathrm{red} 1}\left(0.0067 \mathrm{~s}^{-1}\right)$ is 2200 -fold slower and is independent of the $\mathrm{Br} 4 \mathrm{~A}$ concentration. At low concentrations of $\mathrm{Br} 4 \mathrm{~A}$ (i.e., $0.2 \mathrm{mM}$ ), there is complete $(100 \%)$ conversion of $\mathrm{MCR}_{4 \mathrm{~A}}$ to $\mathrm{MCR}_{\text {red1 }}$ (Figure 6). However, at higher concentrations of $\mathrm{Br} 4 \mathrm{~A}, \mathrm{MCR}_{4 \mathrm{~A}}$ is only partially converted to $\mathrm{MCR}_{\text {red1 }}$ and, at $\mathrm{Br} 4 \mathrm{~A}$ concentrations greater than $8 \mathrm{mM}$, there is no appreciable regeneration and the absorbance at $420 \mathrm{~nm}$ increases to a limiting value in a single exponential fashion. The apparent conundrum is that conversion of alkyl-Ni(III) to $\mathrm{Ni}(\mathrm{I})$ and an alkane requires a two-electron input into the $\mathrm{Ni}$ (III) center and no redox mediators are present; thus, it was important to determine the product of this $\mathrm{MCR}_{\text {red1 }}$ regeneration reaction.

\section{Mass spectrometric (MS) evidence for ester formation from the self-reactivation reaction of MCR $_{4 A}$}

Mass spectrometry was used to identify the product of the self-reactivation reaction of $\mathrm{MCR}_{\text {red1 }}$ with Br4A (Figure 7). In the negative ion mode (NIM), the major peak has an $\mathrm{m} / \mathrm{Z}$ value of 250.8. This corresponds to the molecular formula $\mathrm{C}_{8} \mathrm{H}_{13} \mathrm{O}_{4} \mathrm{Br}$ with an exact mass of 252, which can be assigned to the bromo carboxy ester, 4-(4-bromobutanoyloxy)butanoic acid, Br- $\left(\mathrm{CH}_{2}\right)_{3}-\mathrm{COO}-\left(\mathrm{CH}_{2}\right)_{3}-\mathrm{COOH}$. In NIM, the loss of a proton from the carboxylic terminal group of the bromo-carboxy ester product, $\mathrm{Br}-\left(\mathrm{CH}_{2}\right)_{3}-\mathrm{COO}-\left(\mathrm{CH}_{2}\right)_{3}-\mathrm{COOH}$, will give the expected $\mathrm{m} / \mathrm{Z}$ value of 251 , i.e., $(252$ - 1)/1, consistent with the experimentally observed value (Inset, Figure 7). Confirmation that the product is the ester was obtained by MS-MS analysis of the parent ion peak $(\mathrm{m} / z$ 250.8).

Daughter ion peaks were primarily observed at $\mathrm{m} / \mathrm{z} 149.5,164.8,171.7$ (Figure 7). The peak at $\mathrm{m} / z 171.7$ arises from loss of bromine from the parent ion to give $\mathrm{C}_{8} \mathrm{H}_{13} \mathrm{O}_{4}$, with an exact mass of 173.2, followed by deprotonation of the carboxylic acid to give the negative ion, $\left[\mathrm{C}_{8} \mathrm{H}_{13} \mathrm{O}_{4}\right]^{-}$, with a calculated $\mathrm{m} / \mathrm{z}$ of 172 , i.e, $(252-79=[173-1 / 1]=172)$, the fragment labeled 'c' in Figure 7. Thus, the ester can cleave at different positions marked 'a', 'b', and "c" (Figure 7) to form daughter ions having molecular formulae $\mathrm{C}_{4} \mathrm{H}_{6} \mathrm{O}_{2} \mathrm{Br}$, $\mathrm{C}_{4} \mathrm{H}_{6} \mathrm{OBr}$ and $\mathrm{C}_{8} \mathrm{H}_{13} \mathrm{O}_{4}$, and the peaks marked ' $\mathrm{a}$ ' and ' $\mathrm{b}$ ' agree the experimentally observed $\mathrm{m} / \mathrm{z}$ values of 164.8 and 149.5 , respectively.

When the negative control experiment was performed in absence of enzyme, the product was not observed in either NIM or positive ion mode (PIM); however, a peak corresponding to the bromide was observed in NIM and the remaining fragment after de-bromination, which presumably is a positive species, was observed in PIM. Thus, the reaction of MCR red1 $_{1}$ with Br4A generates the alkyl-Ni(III) species $\mathrm{MCR}_{4 \mathrm{~A}}$. Another molecule of $\mathrm{Br} 4 \mathrm{~A}$ reacts with $\mathrm{MCR}_{4 \mathrm{~A}}$ to generate the ester, 4-(4-bromobutanoyloxy)butanoic acid. Two possible mechanisms by which this condensation could occur are considered in the Discussion.

\section{MCR XA is reactivated to $M C R_{\text {red1 }}$ by thiols}

It has been recently observed that the $\mathrm{MCR}_{\mathrm{PS}}$ complex can be reconverted to active $\mathrm{MCR}_{\text {red1 }}$ by nucleophilic attack of various thiolates on the carbon bound to nickel. To determine if $M C R_{X A}$ reacts similarly with thiols, we incubated the $\mathrm{MCR}_{\mathrm{XA}}$ complexes with HSCoM and followed the decrease in absorbance of $\mathrm{MCR}_{X A}$ at $420 \mathrm{~nm}$ and the increase in $\mathrm{MCR}_{\text {red1 }}$ at $385 \mathrm{~nm}$ (Figure 8). Since $\mathrm{MCR}_{\mathrm{XA}}$ and $\mathrm{MCR}_{\text {silent }}$ have similar UV-visible spectra, we also followed the reaction by EPR spectroscopy (inset, Figure 8).

The rate constant for conversion of the different $\mathrm{MCR}_{\mathrm{XA}}$ species to $\mathrm{MCR}_{\mathrm{red} 1}$ is in the range 0.003-0.012 $\mathrm{s}^{-1}$ (Table 2), which is similar to the rate constant for regeneration by HSCoM of $\operatorname{MCR}_{\mathrm{BS}}\left(\mathrm{k}_{\max }\right.$ of $\left.0.006 \mathrm{~s}^{-1}\right)$ and $\mathrm{MCR}_{\mathrm{PS}}\left(\mathrm{k}_{\max }\right.$ is $\left.0.011 \mathrm{~s}^{-1}\right)$. We did not observe a HSCoM concentration dependence for the rate of conversion of $\mathrm{MCR}_{\mathrm{XA}}$ to $\mathrm{MCR}_{\mathrm{red} 1}$; however, the 
reactions with $\mathrm{MCR}_{\mathrm{BS}}\left(\mathrm{K}_{\mathrm{M}}=17 \mathrm{mM}\right.$, Figure S11) and $\mathrm{MCR}_{\mathrm{PS}}\left(\mathrm{K}_{\mathrm{M}}=2.8 \mathrm{mM}(21)\right)$ exhibit clear hyperbolic binding curves.

Among the different brominated acids shown in Table 2, the percent conversion of $\mathrm{MCR}_{\mathrm{XA}}$ to $\mathrm{MCR}_{\text {red1 }}$ vary, with a maximum of about $80 \%$ conversion of $\mathrm{MCR}_{7 \mathrm{~A}}$ to $\mathrm{MCR}_{\text {red1 }}$ (inset, Figure 8). Any EPR-inactive Ni species that is formed most likely decayed into Ni(II)$\mathrm{MCR}_{\text {silent }}$. Furthermore, we did not observe conversion of $\mathrm{MCR}_{\mathrm{XA}}$, formed from the longer brominated acids $(9,10,11,12,15$ and $16-\mathrm{BrA})$, to $\mathrm{MCR}_{\mathrm{red} 1}$ when these $\mathrm{MCR}_{\mathrm{XA}}$ species are incubated with HSCoM. Perhaps the $\mathrm{MCR}_{\mathrm{XA}}$ complex formed from the longer acids did not reactivate because the active site may be plugged, preventing access of thiols to the active site.

\section{Mass spectrometry evidence that a thioether product is formed from the reaction of $M_{X A}$ and HSCoM}

We used MS in NIM to identify the product of the reaction between $\mathrm{MCR}_{5 \mathrm{~A}}$ and $\mathrm{HSCoM}$, as CoM-S-5A, with an $\mathrm{m} / \mathrm{z}$ value 241.3 , which corresponds to the molecular formula $\mathrm{C}_{7} \mathrm{H}_{14} \mathrm{O}_{5} \mathrm{~S}_{2}$ with an exact mass of 241.3 after loss of a proton (inset, Figure 9). This assignment was confirmed by MS-MS analysis of the parent ion peak at $m / z 241.3$, which yields the fragmentation pattern shown in Figure 9.

Daughter ion peaks were observed at $\mathrm{m} / z$ 140.9, 132.9, 107.0, 99.0 and 81.0. The daughter ion at $\mathrm{m} / \mathrm{z} 132.9$, labeled " $\mathrm{b}$ " is assigned to the 5-thiopentanoic acid fragment, with a molecular formula $\mathrm{C}_{5} \mathrm{H}_{9} \mathrm{O}_{2} \mathrm{~S}$ in which the $\mathrm{C}-\mathrm{S}$ bond is cleaved. The remaining fragment ion is desulfo-CoM with a molecular formula $\mathrm{C}_{2} \mathrm{H}_{4} \mathrm{SO}_{3}$ and $\mathrm{m} / \mathrm{z}$ of 107.0 (fragment labeled 'c'). The daughter ion peak at $\mathrm{m} / \mathrm{z} 140.9$ (peak labeled 'a') corresponds to $\mathrm{C}_{2} \mathrm{H}_{6} \mathrm{O}_{3} \mathrm{~S}_{2}$ with an exact mass of 141.97, which is formed when the thioether (S-C) bond is cleaved on the pentanoic acid side of the thioether group. A secondary ion that is generated from this S-C fragmentation is pentanoate, with an $\mathrm{m} / \mathrm{z}$ of 99.0 (fragment and peak labeled ' $\mathrm{d}$ '). The peak at $m / Z 81.0$, labeled 'e', is assigned to the sulfonate group that is cleaved from various ions.

A negative control experiment performed in the absence of enzyme gave a peak at $\mathrm{m} / \mathrm{Z}$ 242.3, which is only one mass unit higher than the expected product (CoM-S-5A, $\mathrm{m} / \mathrm{z}$ 241.3). In order to confirm if the 242.3 peak corresponds to the product, MS-MS was performed; the resulting fragmentation pattern was not consistent with that observed for CoM-S-5A product, which rules out the possibility of the thioether product in the absence of enzyme.

MS coupled with MS-MS also verified formation of the thioether products from the reactions of $\mathrm{MCR}_{6 \mathrm{~A}}$ and $\mathrm{MCR}_{7 \mathrm{~A}}$ with $\mathrm{HSCoM}$. Thus, the $\mathrm{MS}$ data reveal that the reaction of $\mathrm{HSCoM}$ with $\mathrm{MCR}_{\mathrm{XA}}$ generates a thioether product, like the reaction with $\mathrm{MCR}_{\mathrm{BS}}$ and MCRPS.

\section{Discussion}

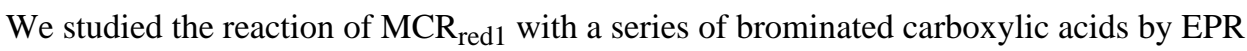
and UV-visible spectroscopy and by kinetics. These reactions, as with BPS, apparently involve nucleophilic attack of $\mathrm{Ni}(\mathrm{I})-\mathrm{MCR}_{\mathrm{red} 1}$ on the terminal carbon adjacent to the bromine atom to eliminate bromide and generate the EPR-active $\mathrm{MCR}_{\mathrm{XA}}$ species. Compounds that give rise to the $\mathrm{MCR}_{\mathrm{XA}}$ EPR signal can be abbreviated as $\mathrm{BrXA}$ and are generalized by the following structure: $\mathrm{Br}-\left(\mathrm{CH}_{2}\right)_{3-15}-\mathrm{COO}^{-}$; where $\mathrm{X}$ is the alkyl linker and is $\sim 3-15$ carbons long, and $\mathrm{A}$ is the terminal anionic carboxylate group. Based on the near identity of the $\mathrm{MCR}_{\mathrm{XA}}$ EPR signal to that of the $\mathrm{MCR}_{\mathrm{PS}}(21)$, we can confidently assign $\mathrm{MCR}_{\mathrm{XA}}$ as a $\mathrm{Ni}(\mathrm{III})$-alkyl carboxylate. As with $\mathrm{MCR}_{\mathrm{PS}}$, the lack of detectable hyperfine splitting from 
the bromide $(I=3 / 2)$ demonstrates that it is not near the paramagnetic center, suggesting that the bromide undergoes elimination in formation of the $\mathrm{MCR}_{\mathrm{XA}}$ state.

The BrXA's were characterized by their reactivity with $\mathrm{MCR}_{\text {red1 }}$ to form $\mathrm{MCR}_{\mathrm{XA}}$ (Table 1), their ability to accumulate $\mathrm{MCR}_{\mathrm{XA}}$ (Table 1), and by the rate at which the respective $\mathrm{MCR}_{\mathrm{XA}}$ complexes react with thiolates ( $\left.\mathrm{SCoM}\right)$ to form $\mathrm{MCR}_{\text {red } 1}$ and the CoMS-XA thioether (Table 2). Accumulation of $\mathrm{MCR}_{\mathrm{XA}}$ (in the absence of the thiolate) is a function of the rate of $\mathrm{MCR}_{\mathrm{XA}}$ formation and its decay to form XA and the EPR-silent $\mathrm{Ni}$ (II) $\mathrm{MCR}_{\text {silent }}$ state. All of these bromoacids form EPR-active $\mathrm{MCR}_{\mathrm{XA}}$ species and fall into two classes, based on their reactivity (Figure S12).

The shorter brominated acids, $\mathrm{Br} 4 \mathrm{~A}$ to $\mathrm{Br} 8 \mathrm{~A}$, react rapidly with $\mathrm{MCR}_{\text {red } 1}$ to form the $\mathrm{MCR}_{\mathrm{XA}}$ state, exhibit high values of $\mathrm{K}_{\mathrm{M}}$ and $\mathrm{k}_{\max }$ for $\mathrm{MCR}_{\mathrm{XA}}$ formation, and accumulate nearly quantitatively in this state; furthermore, these compounds react with HSCoM to form a thioether and regenerate $\mathrm{MCR}_{\text {red1 }}$. These properties indicate that the short bromoacids mimic binding of methyl-SCoM $\left(\mathrm{K}_{\mathrm{M}}=5.0 \mathrm{mM},(31)\right)$, with their carboxylate groups interacting with $\operatorname{Arg} 120$.

The $\mathrm{MCR}_{4 \mathrm{~A}}$ complex formed from the short bromoalkanoic acid, $\mathrm{Br} 4 \mathrm{~A}$, undergoes conversion to $\mathrm{MCR}_{\text {red } 1}$ in the absence of thiolate. One would expect $\mathrm{Br} 4 \mathrm{~A}$ to be reactive, since like BPS (the most potent inhibitor of MCR), its bromide is adjacent to an electrophilic carbon atom that is four bonds ( $4.8 \AA)$ from the negatively charged oxygen of the carboxylate. Accordingly, the $\mathrm{k}_{\max }$ values for formation of $\mathrm{MCR}_{\mathrm{PS}}$ and $\mathrm{MCR}_{4 \mathrm{~A}}$ are nearly identical $\left(\sim 15 \mathrm{~s}^{-1}\right)$. Therefore, we propose that $\mathrm{MCR}_{\text {red1 }}$ reacts with $\mathrm{Br} 4 \mathrm{~A}$ to form $\mathrm{MCR}_{4 \mathrm{~A}}$, an alkyl-Ni(III) species as with the other brominated substrate analogs. However, unlike BPS, with three oxygen atoms on the sulfonate that firmly anchor it to the active site, the carboxylate of Br4A is short of one oxygen, and thus would be held by weaker interactions (as indicated by its high $\mathrm{K}_{\mathrm{M}}$ value). Regardless, it is likely that the alkanoate group is positioned in the active site with the methylene group bound to $\mathrm{Ni}$ and the carboxylate group bound to Arg120. Then, two pathways could be considered for formation of 4-(4bromobutanoyloxy)butanoic acid, the product that is observed by mass spectrometry. In Pathway I, a second molecule of Br4A could enter the active site and nucleophilically attack the nickel-bound electrophilic carbon-4 to form the bromocarboxy ester and $\mathrm{MCR}_{\text {red1 }}$. The nucleophilic attack of the second $\mathrm{Br} 4 \mathrm{~A}$ is similar to the reaction of HSCoM on the MCR XA species (where $X=5-8$ ). In fact, the rate constants for formation of the thioethers and the bromocarboxy ester are similar. Another possibility, shown in pathway II, Figure S13 is that the electrophilic methylene group bound to $\mathrm{Ni}$ in $\mathrm{MCR}_{4 \mathrm{~A}}$ could undergo intramolecular attack by the negatively charged oxygen of the carboxylate to form a five-membered butyrolactone and $\mathrm{MCR}_{\text {red1 }}$. Then, another molecule of $\mathrm{Br} 4 \mathrm{~A}$ would react with the butyrolactone in solution or in the enzyme active site to generate the bromocarboxy ester.

The longer bromoacids, Br9A to Br16A, apparently mimic CoBSH $\left(\mathrm{K}_{\mathrm{M}}=0.2 \mathrm{mM}, 21\right)$ since they bind more tightly to MCR, exhibit second-order rate constants for formation of $\mathrm{MCR}_{\mathrm{XA}}$ that are similar to those for CoBSH in methane synthesis, and accumulate to a much lower extent than the shorter brominated acids. These compounds likely bind with their carboxyl group interacting with the solvent and the positively charged residues at the upper lip of the channel with the bromoalkyl chain reaching toward the nickel center, where it could react rapidly and form the $\mathrm{MCR}_{\mathrm{XA}}$ complex. The unstable alkyl-Ni(III) complex then rapidly decays to an EPR silent Ni(II) state. Perhaps this is due to homolytic cleavage of the nickel carbon bond giving $\mathrm{Ni}(\mathrm{II})-\mathrm{MCR}_{\text {silent }}$ and the corresponding alkanoic acid radical, which could abstract a hydrogen atom from the environment of protein to form the alkanoic acid (21). 


\section{Conclusion}

The present studies reveal that $\mathrm{MCR}_{\text {red1 } 1}$ can react with a wide range of brominated acids giving rise to an alkyl-Ni(III) complex, called $\mathrm{MCR}_{\mathrm{XA}}$, which exhibits UV-visible and EPR spectra that are nearly identical to the $\mathrm{Ni}(\mathrm{III})$-alkylsulfonate species formed from $\mathrm{MCR}_{\mathrm{PS}}$. Thus, the $\mathrm{MCR}_{\mathrm{XA}}$ complex resembles the methyl-nickel(III) species in the first step of one of the mechanisms (Mechanism I) proposed for methane formation from the natural substrates. The present studies reveal the flexibility of the active site of MCR to accommodate a broad array of substrates. The stable $M_{C} R_{X A}$ species (where $X=5-8$ ) can undergo attack by nucleophilic thiols to form a thioether product and regenerate the active $\mathrm{Ni}(\mathrm{I}) \mathrm{MCR}_{\text {red1 }}$ state, while $\mathrm{MCR}_{4 \mathrm{~A}}$ converts to $\mathrm{MCR}_{\text {red1 }}$ in the absence of a thiol. The unexpected reactivity and flexibility of the MCR active site to accommodate a broad range of substrates provides a molecular ruler for the substrate channel in MCR.

\section{Supplementary Material}

Refer to Web version on PubMed Central for supplementary material.

\section{Acknowledgments}

We thank Dr. Ashraf Raza for assistance in running mass spectrometric experiments.

This work was partly supported by a grant from the Department of Energy (SWR, DE-FG03-ER20297) and by an NSF grant (DBI-0552648) that supported Derek Lyons' research as part of a summer REU. The mass spectrometry instrumentation was purchased with funds from an NIH grant (1P20RR17675) to help support the Instrumentation Core of the Redox Biology Center at UNL.

\section{Abbreviations}

MCR

methyl-SCoM

HSCoM

CoBSH

BPS

BBS

MCR $_{\text {red1 }}$

MCR $_{P S}$

$\mathbf{M C R}_{\mathrm{BS}}$

$\operatorname{MCR}_{\mathbf{X A}}$
Methyl-coenzyme $\mathrm{M}$ reductase

methyl-coenzyme $\mathrm{M}$ or, 2-(methylthio)ethanesulfonate

coenzyme $\mathrm{M}$ or, 2-thioethanesulfonate

coenzyme B or N-7-mercaptoheptanoylthreonine phosphate

3-bromopropane sulfonate

4-bromobutane sulfonate

MCR exhibiting the Ni (I) EPR signal

MCR exhibiting alkyl-Ni(III) signal arising from reaction of $\mathrm{MCR}_{\text {red1 }}$ with BPS

MCR exhibiting the alkyl-Ni(III) signal from the reaction of $\mathrm{MCR}_{\text {red } 1}$ with BBS

MCR exhibiting the alkyl-Ni(III) signal from reaction of $\mathrm{MCR}_{\text {red1 }}$ with bromocarboxylic acids

NIM negative ion mode

\section{References}

1. Thauer RK. Biochemistry of methanogenesis: a tribute to Marjory Stephenson. 1998 Marjory Stephenson Prize Lecture. Microbiology. 1998; 144(Pt 9):2377-406. [PubMed: 9782487]

2. DiMarco AA, Bobik TA, Wolfe RS. Unusual coenzymes of methanogenesis. Annu Rev Biochem. 1990; 59:355-94. [PubMed: 2115763] 
3. Ellermann J, Kobelt A, Pfaltz A, Thauer RK. On the role of N-7-mercaptoheptanoyl-O-phospho-Lthreonine (component $\mathrm{B}$ ) in the enzymatic reduction of methyl-coenzyme $\mathrm{M}$ to methane. FEBS Lett. 1987; 220:358-62. [PubMed: 3111890]

4. Kruger M, Meyerdierks A, Glockner FO, Amann R, Widdel F, Kube M, Reinhardt R, Kahnt J, Bocher R, Thauer RK, Shima S. A conspicuous nickel protein in microbial mats that oxidize methane anaerobically. Nature. 2003; 426:878-81. [PubMed: 14685246]

5. Diekert G, Jaenchen R, Thauer RK. Biosynthetic evidence for a nickel tetrapyrrole structure of factor F430 from Methanobacterium thermoautotrophicum. FEBS Lett. 1980; 119:118-20. [PubMed: 7428919]

6. Diekert G, Klee B, Thauer RK. Nickel, a component of factor F430 from Methanobacterium thermoautotrophicum. Arch Microbiol. 1980; 124:103-6. [PubMed: 7377902]

7. Whitman WB, Wolfe RS. Presence of nickel in factor F430 from Methanobacterium bryantii. Biochem Biophys Res Commun. 1980; 92:1196-201. [PubMed: 7370029]

8. Ermler U, Grabarse W, Shima S, Goubeaud M, Thauer RK. Crystal structure of methyl-coenzyme M reductase: the key enzyme of biological methane formation. Science. 1997; 278:1457-62. [PubMed: 9367957]

9. Goubeaud M, Schreiner G, Thauer RK. Purified methyl-coenzyme-M reductase is activated when the enzyme-bound coenzyme F430 is reduced to the nickel(I) oxidation state by titanium(III) citrate. Eur J Biochem. 1997; 243:110-4. [PubMed: 9030728]

10. Rospert S, Bocher R, Albracht SP, Thauer RK. Methyl-coenzyme M reductase preparations with high specific activity from H2-preincubated cells of Methanobacterium thermoautotrophicum. FEBS Lett. 1991; 291:371-5. [PubMed: 1657649]

11. Craft JL, Horng YC, Ragsdale SW, Brunold TC. Nickel oxidation states of F(430) cofactor in methyl-coenzyme M reductase. J Am Chem Soc. 2004; 126:4068-9. [PubMed: 15053571]

12. Harmer J, Finazzo C, Piskorski R, Bauer C, Jaun B, Duin EC, Goenrich M, Thauer RK, Van Doorslaer S, Schweiger A. Spin density and coenzyme M coordination geometry of the ox 1 form of methyl-coenzyme M reductase: a pulse EPR study. J Am Chem Soc. 2005; 127:17744-55. [PubMed: 16351103]

13. Becker DF, Ragsdale SW. Activation of methyl-SCoM reductase to high specific activity after treatment of whole cells with sodium sulfide. Biochemistry. 1998; 37:2639-47. [PubMed: 9485414]

14. Albracht SPJ, Ankel-Fuchs D, Böcher R, Ellermann J, Moll J, van der Zwann JW, Thauer RK. Five new EPR signals assigned to nickel in methyl-coenzyme M reductase from Methanobacterium thermoautotrophicum, strain Marburg. Biochimica et Biophysica Acta. 1988; 955:86-102.

15. Mahlert F, Bauer C, Jaun B, Thauer RK, Duin EC. The nickel enzyme methyl-coenzyme M reductase from methanogenic archaea: In vitro induction of the nickel-based MCR-ox EPR signals from MCR-red2. J Biol Inorg Chem. 2002; 7:500-13. [PubMed: 11941508]

16. Rospert S, Voges M, Berkessel A, Albracht SP, Thauer RK. Substrate-analogue-induced changes in the nickel-EPR spectrum of active methylcoenzyme-M reductase from Methanobacterium thermoautotrophicum. Eur J Biochem. 1992; 210:101-7. [PubMed: 1332856]

17. Hinderberger D, Piskorski RP, Goenrich M, Thauer RK, Schweiger A, Harmer J, Jaun B. A nickelalkyl bond in an inactivated state of the enzyme catalyzing methane formation. Angew Chem Int Ed Engl. 2006; 45:3602-7. [PubMed: 16639771]

18. Goenrich M, Mahlert F, Duin EC, Bauer C, Jaun B, Thauer RK. Probing the reactivity of Ni in the active site of methyl-coenzyme M reductase with substrate analogues. J Biol Inorg Chem. 2004; 9:691-705. [PubMed: 15365904]

19. Ellermann J, Rospert S, Thauer RK, Bokranz M, Klein A, Voges M, Berkessel A. Methylcoenzyme-M reductase from Methanobacterium thermoautotrophicum (strain Marburg). Purity, activity and novel inhibitors. Eur J Biochem. 1989; 184:63-8. [PubMed: 2506016]

20. Brenner MC, Zhang H, Scott RA. Nature of the low activity of S-methyl-coenzyme M reductase as determined by active site titrations. J Biol Chem. 1993; 268:18491-5. [PubMed: 8395504] 
21. Goenrich M, Duin EC, Mahlert F, Thauer RK. Temperature dependence of methyl-coenzyme M reductase activity and of the formation of the methylcoenzyme $M$ reductase red2 state induced by coenzyme B. J Biol Inorg Chem. 2005; 10:333-42. [PubMed: 15846525]

22. Kunz RC, Horng YC, Ragsdale SW. Spectroscopic and kinetic studies of the reaction of bromopropanesulfonate with methyl-coenzyme M reductase. J Biol Chem. 2006; 281:34663-76. [PubMed: 16966321]

23. Lahiri GK, Stolzenberg AM. Facile formation of hexahydroporphyrin complexes by reduction of octaethylisobacteriochlorinnickel(II). Angew.Chem.Int.Ed.Engl. 1993; 32:429-432.

24. Lin S-K, Jaun B. Coenzyme F430 from methanogenic bacteria: detection of a paramagnetic methylnickel(II) derivative of the pentamethyl ester by $2 \mathrm{H}-\mathrm{NMR}$ spectroscopy. Helv. Chem. Acta. 1991; 74:1725-1738.

25. Lin S-K, Jaun B. Coenzyme F430 from methanogenic bacteria: mechanistic studies on the reductive cleavage of sulfonium ions catalyzed by F430 pentamethyl ester. Helv. Chem. Acta. 1992; 75:1478-1490.

26. Horng YC, Becker DF, Ragsdale SW. Mechanistic studies of methane biogenesis by methylcoenzyme M reductase: evidence that coenzyme B participates in cleaving the C-S bond of methyl-coenzyme M. Biochemistry. 2001; 40:12875-85. [PubMed: 11669624]

27. Banerjee R, Ragsdale SW. The many faces of Vitamin-B12: Catalysis by Cobalamin dependent enzymes. Annu Rev Biochem. 2003; 72:209-247. [PubMed: 14527323]

28. Pelmenschikov V, Blomberg MR, Siegbahn PE, Crabtree RH. A mechanism from quantum chemical studies for methane formation in methanogenesis. J Am Chem Soc. 2002; 124:4039-49. [PubMed: 11942842]

29. Pelmenschikov V, Siegbahn PE. Catalysis by methyl-coenzyme M reductase: a theoretical study for heterodisulfide product formation. J Biol Inorg Chem. 2003; 8:653-62. [PubMed: 12728361]

30. Wackett LP, Honeck JF, Begley TP, Wallace V, Orme-Johnson WH, Walsh CT. Substrate analogues as mechanistic probes of methyl-S-coenzyme M reductase. Biochemistry. 1987; 26:6012-6018. [PubMed: 3120769]

31. Zehnder AJ, Wuhrmann K. Titanium (III) citrate as a nontoxic oxidation-reduction buffering system for the culture of obligate anaerobes. Science. 1976; 194:1165-6. [PubMed: 793008]

32. Schonheit P, Moll J, Thauer RK. Nickel, cobalt, and molybdenum requirement for growth of Methanobacterium thermoautotrophicum. Arch Microbiol. 1979; 123:105-7. [PubMed: 120728] 

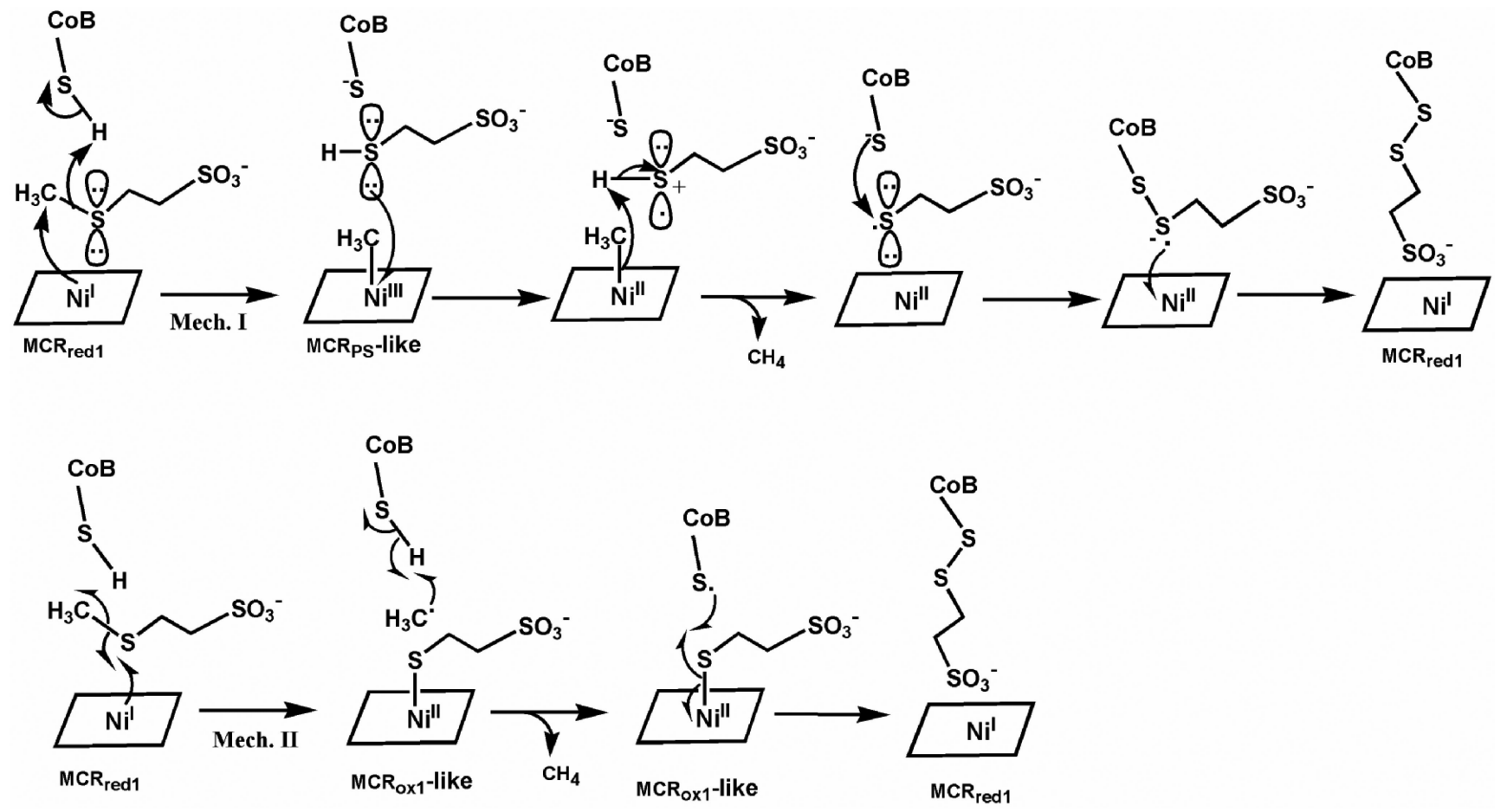

Figure 1.

Relationship between $\mathrm{MCR}_{\mathrm{Ox} 1}, \mathrm{MCR}_{\mathrm{PS}}$ and the two proposed mechanisms for MCR. 


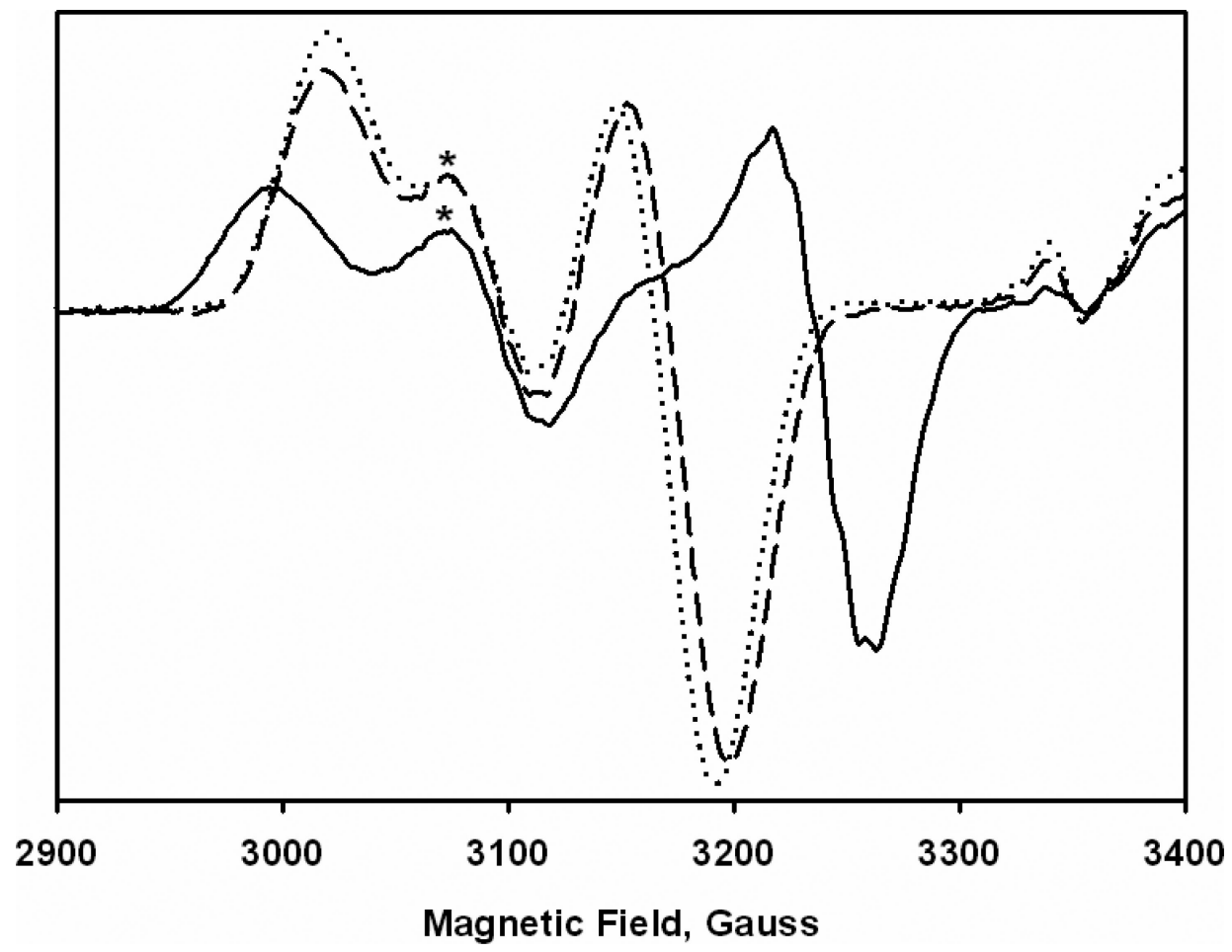

Figure 2.

EPR spectra of $\mathrm{MCR}_{7 \mathrm{~A}}$ formed from the reaction of $\mathrm{MCR}_{\text {red1 }}$ with Br7A. MCR $\mathrm{M}_{\text {red1 }}(20.6$ $\mu \mathrm{M}$ (solid line)) was incubated with $1 \mathrm{mM} \mathrm{Br7A}$ (dashed line) or $548 \mu \mathrm{M}$ BPS (dotted line) in $50 \mathrm{mM}$ Tris- $\mathrm{HCl}(\mathrm{pH} 7.6)$ with $0.1 \mathrm{mM} \mathrm{Ti}(\mathrm{III})$ citrate at $20^{\circ} \mathrm{C}$. ${ }^{*}$ Contamination from $\mathrm{MCR}_{\mathrm{Ox} 1}$. 


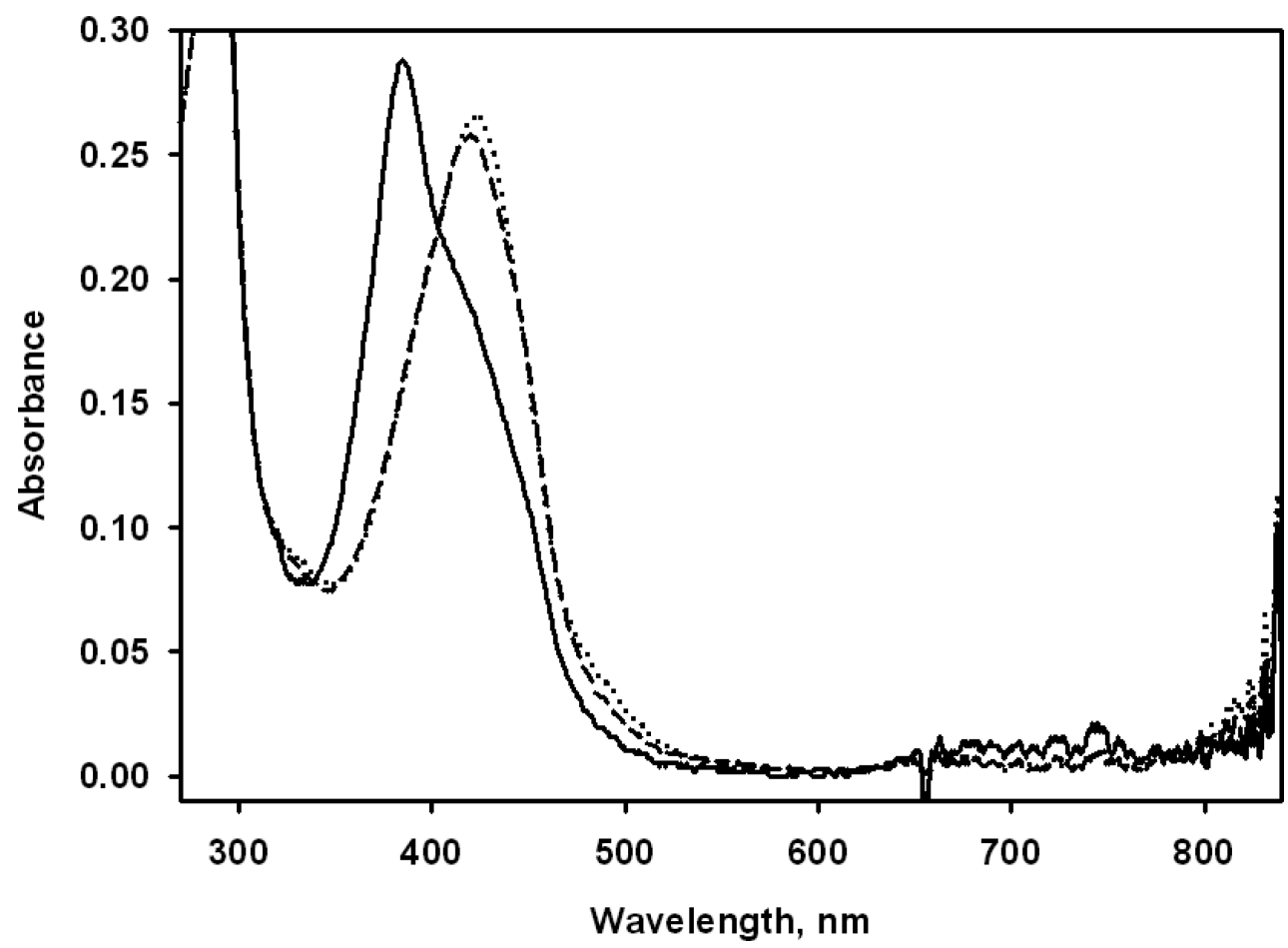

Figure 3.

UV-visible spectral changes associated with reaction of $\mathrm{MCR}_{\text {red1 }}$ with $\mathrm{Br} 7 \mathrm{~A}$ and BPS. $\mathrm{MCR}_{\text {red1 }}(8.2 \mu \mathrm{M}$ (solid line)) was incubated with $400 \mu \mathrm{M}$ Br7A (dashed line) or $219 \mu \mathrm{M}$ BPS (dotted line) in $50 \mathrm{mM}$ Tris- $\mathrm{HCl}$ (pH 7.6) with $0.1 \mathrm{mM} \mathrm{Ti}(\mathrm{III})$ citrate at $20^{\circ} \mathrm{C}$. 


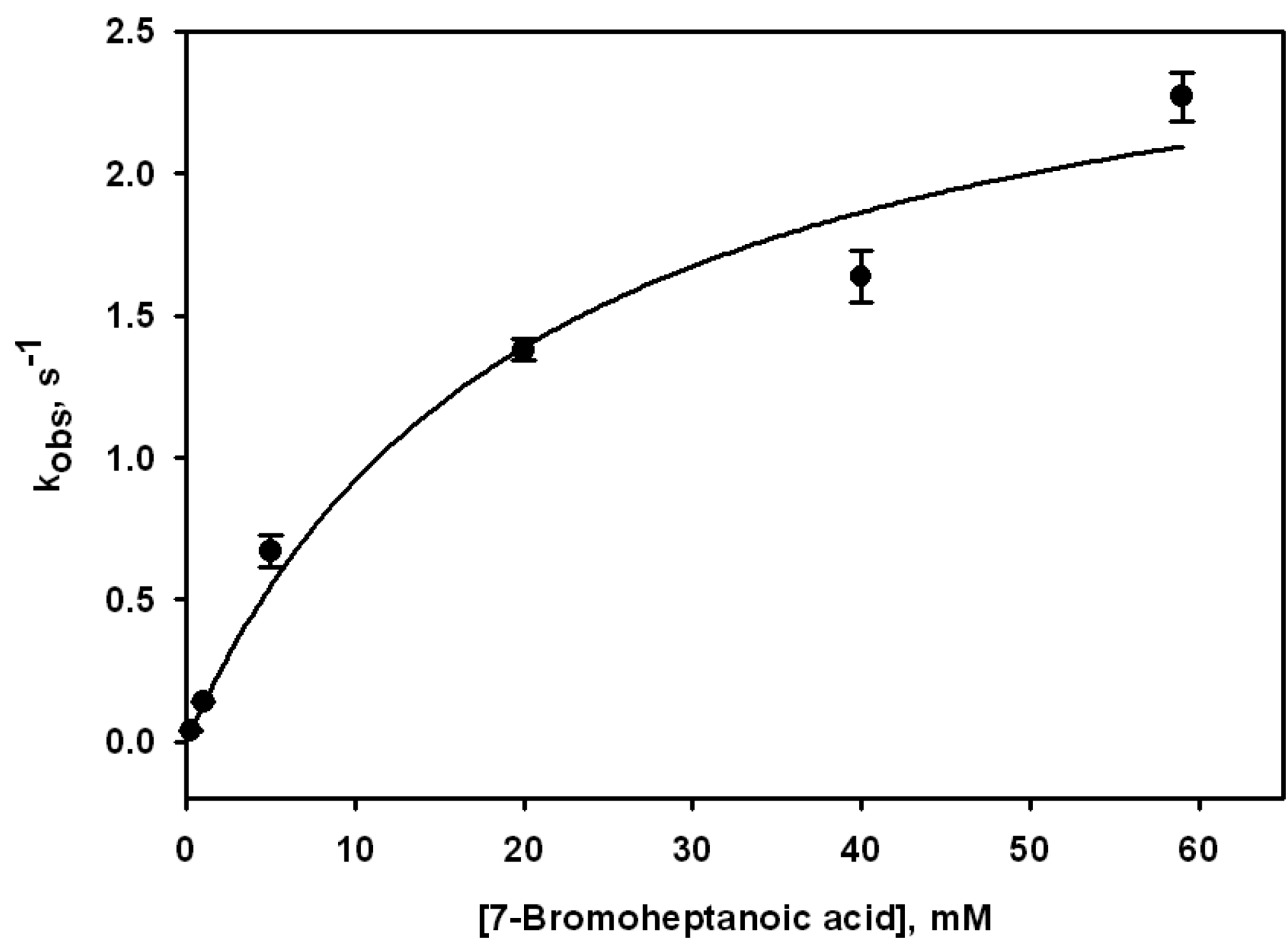

Figure 4.

Dependence of $\mathrm{k}_{\mathrm{obs}}$ for $\mathrm{MCR}_{7 \mathrm{~A}}$ on Br7A concentration. $10 \mu \mathrm{M} \mathrm{MCR}_{\text {red1 }}$ was converted to $\mathrm{MCR}_{7 \mathrm{~A}}$ by the addition of different concentrations of Br7A in $0.5 \mathrm{M}$ Tris- $\mathrm{HCl}, \mathrm{pH} 7.6$ containing $0.2 \mathrm{mM} \mathrm{Ti}$ (III) citrate. The data were fit to a 2-parameter hyperbolic equation with a $\mathrm{k}_{\max }$ of $2.8 \pm 0.4 \mathrm{~s}^{-1}$ and $\mathrm{K}_{\mathrm{M}}$ of $21 \pm 8 \mathrm{mM}$ and a second order rate constant of $140 \pm$ $57 \mathrm{M}^{-1} \mathrm{~s}^{-1}$. 
<smiles>O=C([O-])CC(CCCCCCCBr)CC(=O)[O-]</smiles><smiles>C[C@@H](OP(=O)([O-])O)[C@@H](NC(=O)CCCCCCS)C(=O)[O-]</smiles>

Figure 5.

Comparison of the structures of Br11A and CoBSH. Two alternative conformations (a and b) are shown by the solid and dotted lines. 


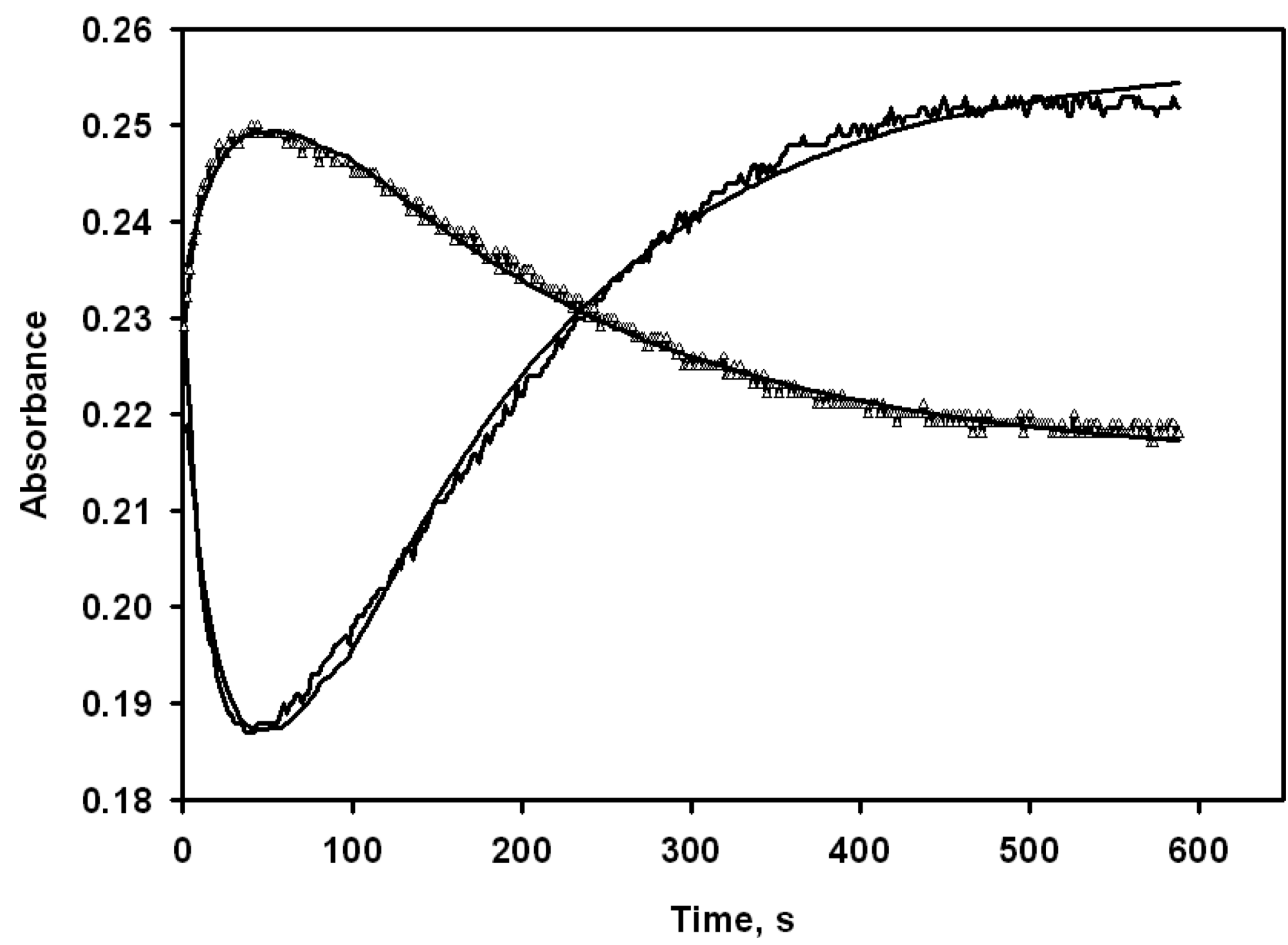

Figure 6.

Formation of $\mathrm{MCR}_{4 \mathrm{~A}}$ followed by regeneration of $\mathrm{MCR}_{\text {red1 }}$. The formation or decay of $\mathrm{MCR}_{4 \mathrm{~A}}$ and $\mathrm{MCR}_{\text {red1 }}$ were monitored at $385 \mathrm{~nm}$ (solid line) and $420 \mathrm{~nm}$ (open triangles) by UV-visible spectroscopy. $\mathrm{MCR}_{\mathrm{red} 1}(10 \mu \mathrm{M})$ was reacted with $0.2 \mathrm{mM} \mathrm{Br} 4 \mathrm{~A}$ in $200 \mathrm{mM}$ ammonium carbonate, $\mathrm{pH} \sim 10$. The data were fit to three-component sequential equations with the following parameters: for the absorbance changes at $385: \mathrm{k}_{1}, 0.037 \pm 0.003 \mathrm{~s}^{-1} ; \mathrm{k}_{2}=$ $0.0067 \pm 0.0003 \mathrm{~s}^{-1}$; for the absorption changes at $420 \mathrm{~nm}: k_{1}, 0.036 \pm 0.0010 \mathrm{~s}^{-1}, \mathrm{k}_{2} 0.0054$ $\pm 0.0007 \mathrm{~s}^{-1}$. 


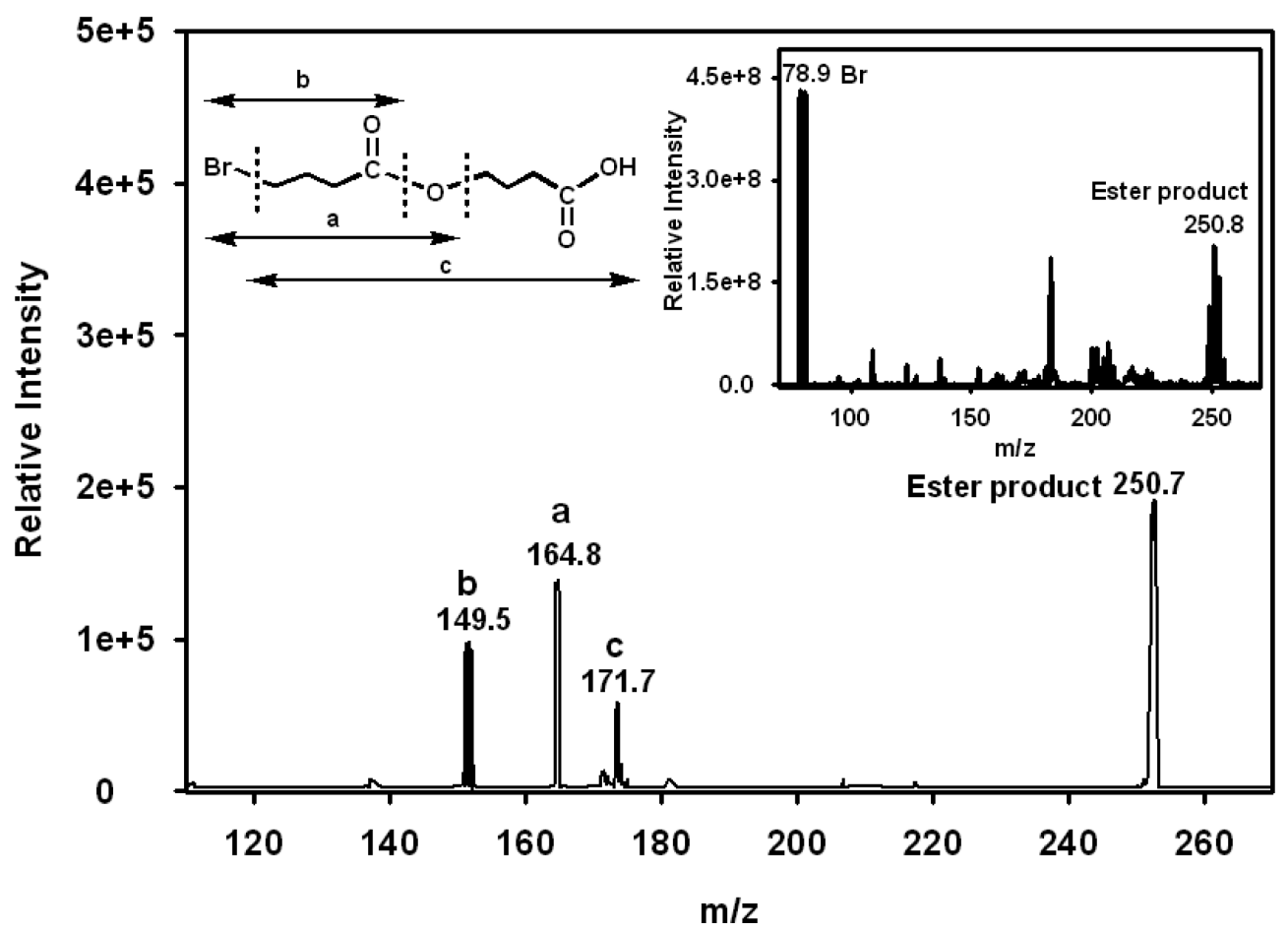

Figure 7.

NIM MS-MS identification of the fragmented/daughter ions from the bromocarboxy ester product formed from the "self-reactivation" of $\mathrm{MCR}_{4 \mathrm{~A}}$ to $\mathrm{MCR}_{\text {red1 }}$. MCR $\mathrm{MCd}_{\text {red }}(10 \mu \mathrm{M})$ was reacted with $2.0 \mathrm{mM} \mathrm{Br} 4 \mathrm{~A}$ in $20 \mathrm{mM}$ ammonium carbonate, $\mathrm{pH} \sim 10$. Inset: NIM ES-MS identification of the bromo-carboxy ester product formed from the "self-reactivation" of $\mathrm{MCR}_{4 \mathrm{~A}}$ to $\mathrm{MCR}_{\text {red1 }}$. 


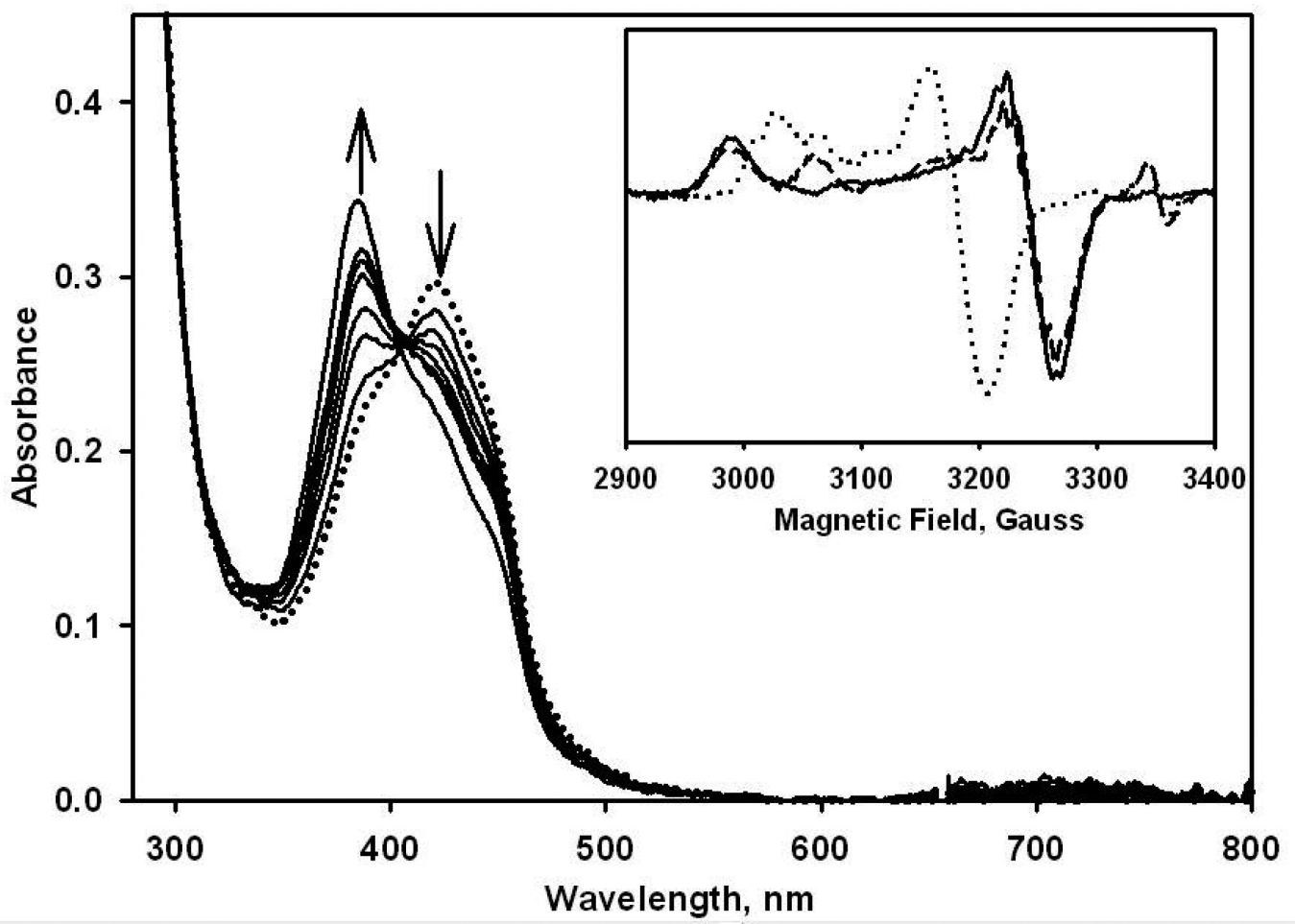

Figure 8.

UV-visible spectral changes associated with the regeneration of $\mathrm{MCR}_{\mathrm{red} 1}$ from $\mathrm{MCR}_{7 \mathrm{~A}}$ incubated with $20 \mathrm{mM}$ HSCoM. MCR $_{\text {red1 }}(11.52 \mu \mathrm{M}$ (solid line)) was treated with $100 \mu \mathrm{M}$ Br7A (dotted line) and the $\mathrm{MCR}_{7 \mathrm{~A}}$ formed was incubated with $20 \mathrm{mM}$ HSCoM in $1 \mathrm{M}$ TAPS-Na ( $\mathrm{pH} \sim 10)$ at $20^{\circ} \mathrm{C}$ and the absorbance was recorded every 6 mins for over 40 mins. Inset: Representative EPR spectra of $\mathrm{MCR}_{\text {red1 }}$ (solid line) $\mathrm{MCR}_{7 \mathrm{~A}}$ (dotted line) and regeneration of $\mathrm{MCR}_{7 \mathrm{~A}}$ to $\mathrm{MCR}_{\mathrm{red} 1}$ (dashed line). 


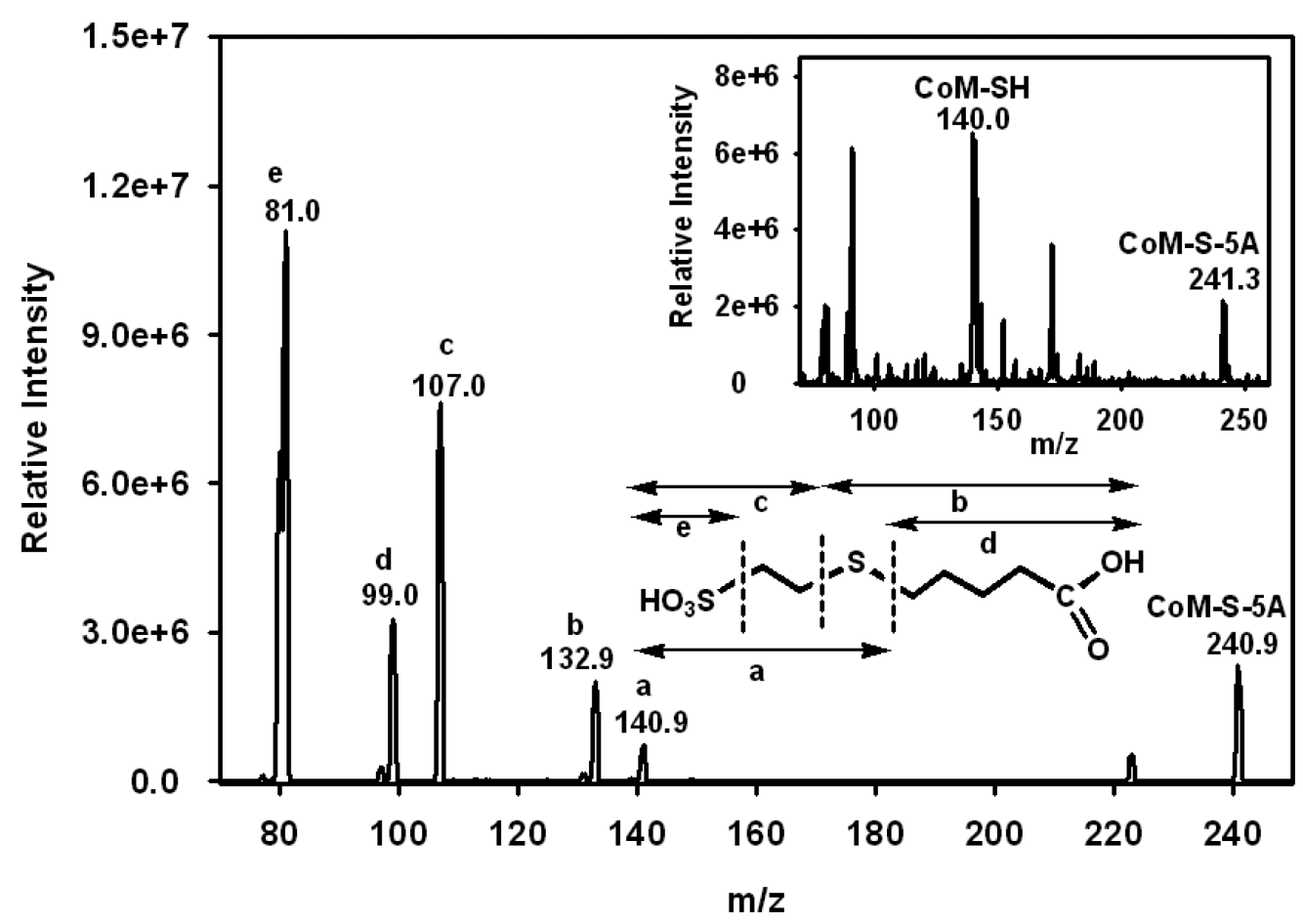

Figure 9.

NIM-MS/MS spectrum of the product of the reaction of MCR $_{5 A}$ with HSCoM. $20 \mu \mathrm{M}$ $\mathrm{MCR}_{\text {red1 }}$ was reacted with $1 \mathrm{mM} \mathrm{Br} 5 \mathrm{~A}$ to form $\mathrm{MCR}_{5 \mathrm{~A}}$, which was reacted with $1 \mathrm{mM}$ HSCoM in $500 \mathrm{mM}$ ammonium carbonate $\mathrm{pH} \sim 10.0$. Inset: Original NIM-MS spectrum of the reaction product. 


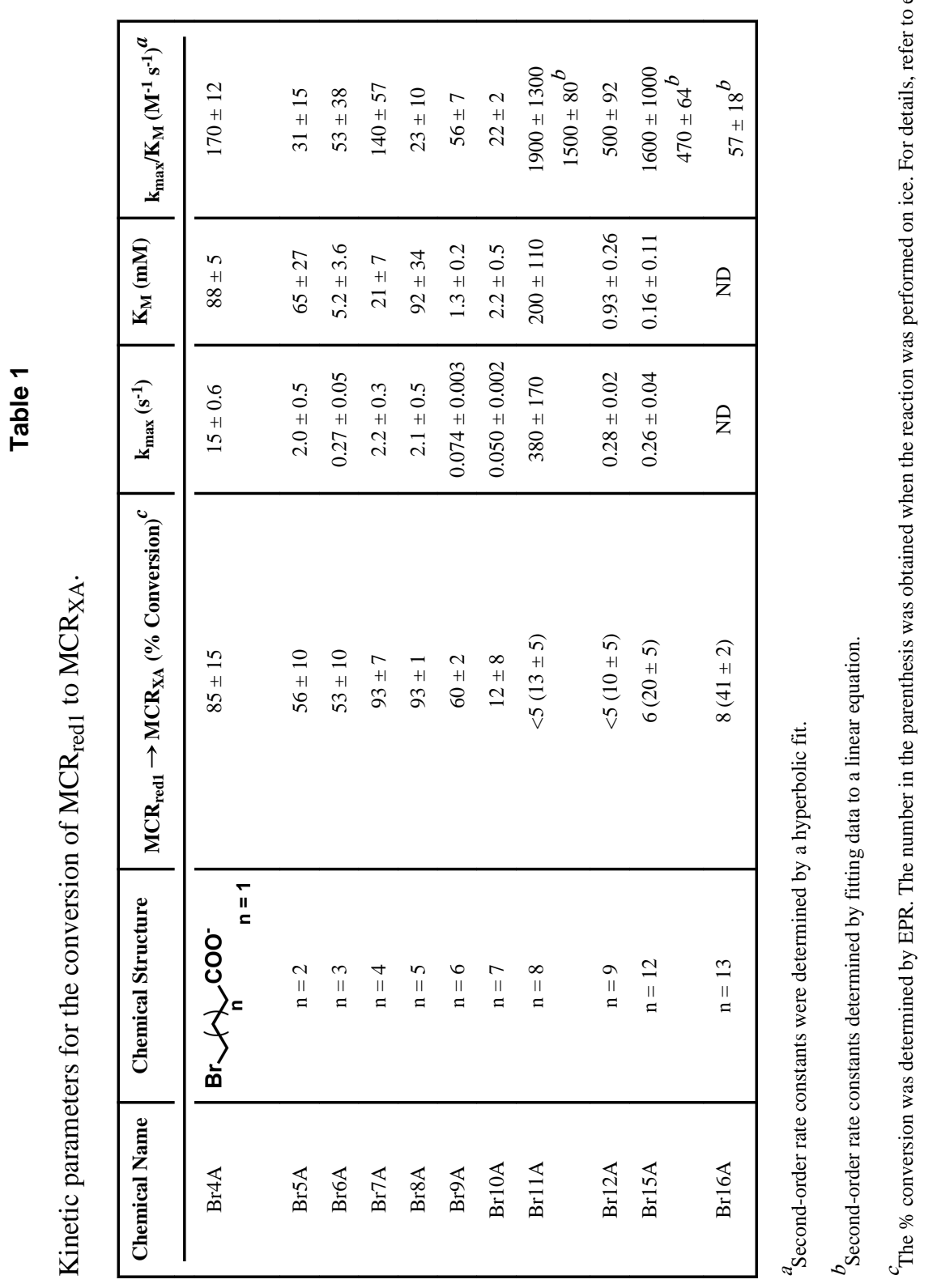

Biochemistry. Author manuscript; available in PMC 2013 January 23. 
Table 2

Regeneration of $\mathrm{MCR}_{\mathrm{red} 1}$ from $\mathrm{MCR}_{\mathrm{XA}}$ using $20 \mathrm{mM}$ HSCoM. Experiments were performed in $0.5 \mathrm{M}$ TAPS (pH 10) at $25^{\circ} \mathrm{C}$.

\begin{tabular}{|cccc|}
\hline Chemical Name & Reactivation of $\mathbf{M C R}_{\mathbf{X A}}$ & $\mathbf{M C R}_{\mathbf{X A}} \rightarrow \mathbf{M C R}_{\text {red1 }}(\boldsymbol{\%}$ reactivation $)$ & $\boldsymbol{a}$ \\
\hline Br5A & Yes & 46 & $0.012+0.001$ \\
Br6A & Yes & $\left.\mathbf{s}^{\mathbf{- 1}}\right)$ \\
Br7A & Yes & 65 & $0.006 \pm 0.001$ \\
Br8A & Yes & 81 & $0.006 \pm 0.001$ \\
Br9A & No & 31 & $0.003 \pm 0.001$ \\
\hline
\end{tabular}

${ }^{a}$ The $\%$ reactivation represents the percentage conversion of MCRXA to MCR red1. For details of experimental conditions, refer to experimental section. 